\title{
Myoclonus in the critically ill: Diagnosis, management and clinical impact
}

Raoul Sutter, MD ${ }^{1,2}$, Anette Ristic, MD¹, Stephan Rüegg, MD $^{2}$, Peter Fuhr, MD²

${ }^{1}$ Clinic for Intensive Care Medicine, University Hospital Basel, Basel, Switzerland

${ }^{2}$ Division of Clinical Neurophysiology, Department of Neurophysiology, University Hospital

Basel, Basel, Switzerland

\section{Corresponding author:}

Raoul Sutter, MD, Ass. Professor

Department of Neurology and Intensive Care Unit, University Hospital Basel, Petersgraben 4, 4031 Basel, Switzerland

Tel.: +41612652525

E-mail: Raoul.Sutter@usb.ch

Institution where the work was performed: University Hospital Basel, Switzerland. 


\section{Abstract}

Myoclonus is the second most common involuntary non-epileptic movement in intensive care units following tremor-like gestures. Although there are several types of myoclonus, they remain underappreciated and their diagnostic and prognostic associations are largely ignored.

This review discusses clinical, electrophysiological, neuroanatomical, and neuroimaging characteristics of different types of myoclonus in critically ill adults along with their prognostic impact and treatment options.

Myoclonus is characterized by a sudden, brief, and sometimes repetitive muscle contraction of body parts, or a brief and sudden cessation of tonic muscle innervation followed by a rapid recovery of tonus. Myoclonus can resemble physiologic and other pathologic involuntary movements. Neurologic injuries, anesthetics, and muscle relaxants interfere with the typical appearance of myoclonus. Identifying "real myoclonus" and determining the neuroanatomical origin is important, as treatment responses depend on the involved neuroanatomical structures. The identification of the type of myoclonus, the involved neuroanatomical structures and the associated illnesses is essential to direct treatment.

In conclusion, the combined clinical, electrophysiological and neuroradiological examination reliably uncovers the neuroanatomical sources and pathophysiology of myoclonus. Recognizing cortical myoclonus is critical, as it is treatable and may progresses to generalized convulsive seizures or status epilepticus.

Keywords: Myoclonus; diagnosis; treatment; prognosis; critical illness; neurocritical care. 


\section{Introduction}

Myoclonus is the second most common involuntary non-epileptic movement in intensive care units (ICUs) following tremor-like motions (Benbadis et al.,2010). However, myoclonic jerks are not pathognomonic of any particular disease.

Despite the growing body of evidence that myoclonus accompanies a number of critical illnesses, it remains underappreciated and its diagnostic and prognostic impact is largely ignored.

The aim of this review is to provide a comprehensive overview of the clinical, electrophysiological, neuroanatomical, and neuroimaging characteristics of the different types of myoclonus in critically ill adult patients along with the prognostic impact in critical care and current treatment options.

\section{Definition, phenomenology and clinical classification of myoclonus}

Myoclonus is a sudden, brief, abrupt twitching of body parts involving the face, extremities, and trunk(Fahn et al.,1986) caused by an abnormally increased excitability of neurons leading to muscle contractions (i.e., positive myoclonus), or a sudden brief loss of muscle tonus followed by a rapid recovery of tonus (i.e., negative myoclonus) that may appear in clusters called "flapping tremor" or "asterixis"(Artieda et al.,1992; Butz et al.,2014; Shibasaki,1995; Young and Shahani,1986) and can be associated with epileptic events(Baumgartner et al.,1996; Belcastro et al.,2011; Meletti et al.,2000; Rubboli et al.,1995; Song et al.,2006; Tassinari et al.,1995) (Figure 1). Involved muscles, temporal distribution, synchronization, relation to motor activity, and stimulus sensitivity can be observed and categorized clinically and may direct diagnostic procedures for neuroanatomical and etiological categorization, which assists the choice of treatment(Shibasaki,2002) (Table 1). 
The EMG activity during myoclonus does usually not exceed 200 milliseconds and duration of $<50$ milliseconds represents epileptic myoclonus. The study of myoclonus begins with the clinical observation and examination. The neuroanatomical site of involvement, rhythmicity, periodicity, stimulus sensitivity, mode of effective triggers, accompanying clinical signs, and specific electrophysiologic and neuroimaging patterns are important features that help consolidating the diagnosis.

\section{Etiological classification of myoclonus}

\subsection{Symptomatic myoclonus in the ICU}

A large variety of critical illnesses, medication, and illicit drugs may be associated with different types of myoclonus (Table 2).

Myoclonus can be triggered or aggravated by a large number of different drugs used in intensive care including opioids, such as hydromorphone(Babul and Darke,1992; Patel et al.,2006), morphine(Potter et al.,1989), fentanyl(Stuerenburg et al.,2000), non-steroidal anti-inflammatory drugs(Bandelot and Mihout,1978), neuroleptics(Pedavally et al.,2014; Strachan and Benoff,2006; Vural and Tezer,2012), antiepileptic drugs in high doses, such as carbamazepine(Magaudda and Di Rosa,2012), oxcarbazepine(Fanella et al.,2013), lamotrigin(Algahtani et al.,2014), topiramate(Miller et al.,2010), pregabalin and gabapentin(Ege et al.,2008; Healy et al.,2009; Hellwig and Amtage,2008), phenytoin(Duarte et al.,1996), and valproic acid(Gardner et al.,2009), antidepressants(Caviness and Evidente,2003; Evidente and Caviness,1999; Praharaj et al.,2010), the amino acid precursor of dopamine - levodopa(Yoshida et al.,1993) and bromocriptine(Buchman et al.,1987), antibiotics such as imipenem(Frucht and Eidelberg,1997), cefepime(Fugate et al.,2013), penicillin(Sackellares and Smith,1979), gentamycin(Sarva and Panichpisal,2012), ciprofloxacin(Jayathissa et al.,2010), piperazine(Kompf and 
Neundorfer,1974), antihistamines(Irioka et al.,2008), and chemotherapeutics(Denison and Alghzaly,2006; Savica et al.,2011; Wyllie et al.,1997). Some anesthetics have also ben associated with the emergence and aggravation of myoclonus including etomidate(Laughlin and Newberg,1985; Lumley and Morgan,1985), propofol(Tam et al.,2009), and enflurane( $\mathrm{Ng}, 1980)$. In contrast, deep anesthesia and muscle relaxants may attenuate myoclonus. Additional substances that may trigger myoclonus are heavy metals including aluminium(Russo et al.,1992), bismuth(Teepker et al.,2002), lead(Hansen and Sharp,1978), magnanese(Ono et al.,2002), and the use or withdrawal of illicit drugs, such as cocaine(Scharf,1989), tetrahydrocannabinol(Lozsadi et al.,2004), and alcohol(Drake,1983). Most drug-related myocloni are generated from the cerebral cortex with or without involvement of subcortical structures.

Aside from illicit drugs and medication, cortical myoclonus can emerge with critical illnesses including epilepsy, particularly with epilepsia partialis continua(Lim et al.,2004), nonconvulsive seizures and status epilepticus (Fernandez-Torre and DiazCastroverde,2004; Sutter et al.,2012), and progressive myoclonus epilepsy(Berkovic et al.,1991). Epileptic myoclonus can be the only seizure manifestation, one component of seizure related symptoms, or a more stable condition that is manifested in a non-paroxysmal fashion mimicking other movement disorders. This complex correlation is more obvious with epilepsia partialis continua (EPC) in which cortical myoclonus and overt focal motor seizures start in the same cortical area. In the literature there are only few epilepsy syndromes reported in critically ill adult patients with myoclonus such as EPC, nonconvulsive seizures, or status epilepticus(Sutter et al.,2012).

Myoclonus can also be linked to severe hypoxic brain injury after cardiac arrest (posthypoxic myoclonus)(Werhahn et al.,1997; Wijdicks et al.,1994) or to mild 
hypoxic brain injury or decompression sickness (caisson disease) with restorage of consciousness (i.e., Lance-Adams syndrome)(Lance and Adams,1963; Yamaoka et al.,1994). The differentiation between myoclonus from sever hypoxic-ischemic brain injury and Lance-Adams syndrome and their different impact on outcome will be discussed below. Additional critical medical conditions associated with subcortical myoclonus are metabolic encephalopathies seen in patients with severe uremia(Artieda et al.,1992; Stark,1981; Tedeschi et al.,1982), liver failure(Butz et al.,2014), with infectious, autoimmune, or paraneoplastic encephalitides (Table 2), with heatstroke-related brain injury(Bazille et al.,2005), or with the posterior reversible encephalopathy syndrome(Boland et al.,2012). Less frequent critical illnesses that can present with myoclonus are HIV encephalopathy(Canafoglia et al.,2003; Kanjanasut et al.,2010) and prion diseases, such as Creutzfeldt-Jakob disease(Binelli et al.,2010; Chen et al.,2010). Myoclonus generated from spinal cord segments can be associated with traumatic spinal cord injury(Calancie,2006), spinal cord tumors(Massimi et al.,2009), the stiff man syndrome (Meinck et al.,1995), and with the progressive encephalomyelitis with rigidity and myoclonus (PERM)(Kraemer and Berlit,2008; Kyskan et al.,2013; Shugaiv et al.,2013; Spitz et al.,2004). Peripheral myoclonus is typically associated with lesions of the peripheral nerves(Assal et al.,1998; Hudson et al.,2013).

\subsection{Potential misinterpretation of non-ICU-related myoclonus}

The etiologies of non-ICU-related myoclonus (including physiologic myoclonus, hereditary and epileptic myoclonus, and psychogenic myoclonus) differ from ICUrelated myoclonus. Although these types of myoclonus are rarely seen in the ICUs, awareness and recognition of typical non-ICU-related myoclonus can avoid inadequate treatment escalation. 
The most frequent physiologic myoclonic jerks are compiled in Table 1. Startle, a stereotypical myoclonic response to stimuli(Bakker et al.,2006), hiccups, and sleep onset myoclonus are distinctive and need to be distinguished from non-physiologic myoclonus in intensive care. Multifocal appearances can be misinterpreted as myoclonus from metabolic or hypoxic related brain dysfunction, and bilaterally synchronous myoclonus can resemble discharges from the brainstem reticular formation or cortical discharges from epileptic seizures.

Although autosomal-dominantly inherited syndromes are rare and more frequently seen in outpatients (Table 1), they should be considered in critically ill patients without other plausible causes and family history should be screened. Hereditary myoclonic-dystonia begins in childhood, and may be combined with psychiatric symptoms(Nardocci,2011). Typically, alcohol and activities such as walking and concentrating during reading reduce the jerks. In hereditary hyperekplexia, brisk and generalized startle emerges after acoustic or tactile stimulation without habituation to repeated stimulation or attenuation with pre-warning(Bakker et al.,2006). In a study of 9 patients and 20 controls, the head retraction reflex, described as a vestigial withdrawal reflex elicited by taps to the midline of the face, is characteristic in hereditary and acquired hyperekplexia(Tijssen et al.,1997b). According to a study of 28 patients, it may also be encountered in a variety of disorders, such as basal ganglia disease, amyotrophic lateral sclerosis, and the stiff person syndrome (Berger and Meinck,2003; Sandyk,1982).

Myoclonus during syncope is difficult to separate from seizures, as shown in a videometric analysis of 56 episodes of transient cerebral hypoxia. In contrast to epileptic myoclonus, syncope related myoclonus appears multifocal(Lempert et al.,1994) after the individual has fallen, and lasts 1-16 seconds. The recognition of myoclonus associated with transient cerebral hypoxia is important in the context of 
critically ill patients, as during intensive care, patients can suddenly develop episodes of severe arterial hypotension that (if detected early) can be treated with vasopressors to avoid hypoxic brain injury.

Distinguishing psychogenic from somatic myoclonus is challenging calling for exclusion of somatic diseases. In a case series of patients with psychogenic myoclonus, $>50 \%$ had segmental, almost $40 \%$ had generalized, and $5 \%$ had focal myclonus(Monday and Jankovic,1993). Stress and anxiety precipitated and exacerbated the jerks in $80 \%$. The combination of the following clinical characteristics helps uncovering the psychogenic nature of myoclonic jerks: clinical features incongruous with "organic" myoclonus, evidence of psychopathologies, improvement with distraction, and the presence of incongruous sensory loss or false weakness. However, distinguishing somatic from psychogenic myoclonus can be difficult, especially in patients with movements that resemble propriospinal myoclonus. Detection of a „Bereitschaftspotential“ by EEG-EMG back averaging analysis (technique discussed below) and exclusion of spinal lesions on brain imaging can be helpful in differentiating between these two entities. Hence, advanced electrophysiological techniques and neuroimaging are invaluable in establishing the psychogenic origin of jerky movements in addition to the clinical features.

\subsection{The neuroanatomical classification}

The allocation of specific types of myoclonus in the ICU to involved neuroanatomical structures is essential to direct treatment. Table 3 compiles important clinical differences between cortical, subcortical, spinal, and peripheral myoclonus.

\subsubsection{Cortical myoclonus in the ICU}


Cortical myoclonus can be stimulus sensitive and elicited by tendon taps or touching, by posturing, passive or volitional movements, and by emotional excitation. However, stimulus sensitivity can be absent or difficult to identify clinically. Myoclonus of cortical origin appears as positive or negative myoclonus independently of each other or in combination(Shibasaki and Hallett,2005) and is observed in many critical illnesses (Table 2) such as progressive myoclonus epilepsy(Berkovic et al.,1991), EPC(Lim et al.,2004), hypoxic brain injury(Lance and Adams,1963; Werhahn et al.,1997; Wijdicks et al.,1994; Yamaoka et al.,1994), intoxication, metabolic or drugrelated encephalopathies(Artieda et al.,1992; Stark,1981; Tedeschi et al.,1982). The latter two are also linked to subcortical myoclonus(Chen et al.,2010; Hansen and Sharp,1978; Ono et al.,2002; Teepker et al.,2002). Drugs associated with the emergence of (mostly cortical) myoclonus are described above and presented in Table 2.

In contrast to non-cortical myoclonus, cortical myoclonus may progress into convulsive seizures or status epilepticus regardless of etiology(Obeso et al.,1985). Often, the cortical nature of myoclonus cannot be determined clinically calling for an electrophysiological workup.

Treatment responsiveness and prognosis of cortical myoclonus are primarily determined by the etiology. Potentially reversible conditions include intoxication, drug-related encephalopathies, and myoclonus in association with epilepsies. Intoxication related myoclonus can often be treated by stopping the offending drugs or by gastric lavage. Myoclonus in association with epilepsies can respond to antiepileptic treatment, and myoclonus related to metabolic encephalopathies can ameliorate once the metabolic derangement can be controlled. In contrast, myoclonus associated with prion diseases(Centers of Disease Control and Prevention,2015) and hypoxic brain injury is usually treatment refractory and linked to 
a high mortality of up to $100 \%($ Stevens and Sutter,2013). However, in a recent study of patients with myoclonus after hypoxic brain injury, $9 \%$ had good functional outcomes (Cerebral Performance Category 1-2), mainly patients without associated epileptiform activity(Seder et al.,2015). Hence, myoclonus of itself should not be considered a certain sign of adverse outcome in this context. Table 4 compiles the current evidence of the prognostic value of myoclonus in patients with hypoxicischemic encephalopathy. The differentiation between myoclonus from severe hypoxic brain injury and the more benign and mostly multifocal action and stimulussensitive myoclonus in Lance-Adams syndrome is crucial, as the latter is mostly linked to a favorable neurofuntional outcome(Lance and Adams, 1963; Yamaoka et al.,1994). In contrast to severe postanoxic encephalopathy where the patients' mental status persists as comatose, the majority of patients with Lance-Adams syndrome regain consciousness. Some reports suggested that "giant" somatosensory evoked potentials ("giant" SSEPs described below), usually seen in patients with cortical myoclonus can distinguish patients with severe postanoxic encephalopathy from Lance-Adams syndrome. However, there are also reports describing "giant" SSEPs in patients with Lance Adams syndrome(Werhahn et al.,1997). Myoclonus in the Lance-Adams syndrome usually develops later (several days to months after the insult) than myoclonus from severe hypoxic-ischemic encephalopathy and persists without an EEG correlate. In contrast, myoclonus with severe hypoxic encephalopathy usually occurs within two days after cardiorespiratory arrest(English et al.,2009). Cerebral neuroimaging studies are not useful for the diagnosis of Lance-Adams syndrome with the exception of brain single photon emission computed tomography (SPECT) and brain positron emission tomography (PET). Compared with control groups, patients with Lance-Adams syndrome have increased glucose metabolism in the pontine tegmentum, mesencephalon, and 
ventrolateral thalamus on PET(Frucht et al.,2004) and hypoperfusion in the temporal lobe on brain SPECT(Zhang et al.,2007).

\subsubsection{Subcortical myoclonus in the ICU}

Subcortical myoclonus includes periodic, dystonic, and reticular reflex myoclonus, startle syndrome, and palatal tremor (formerly palatal myoclonus)(Shibasaki and Hallett,2005). Whether palatal jerks represent myoclonus has been controversial. The term "palatal tremor" is used more often, because of the particularly rhythmic and non-"shock-like" jerks (discharge duration >200 milliseconds). The only clinical context in which symptomatic palatal tremor can be seen in the ICU is in patients with lesions in the Guillain-Mollaret triangle or the cerebellum, involving the levator palatine muscle(Deuschl et al.,1994). In this context, the palatal tremor is often accompanied with ocular or limb movements. In contrast to symptomatic palatal tremor, essential palatal tremor involves the tensor veli palatini leading to "clicks" in the ears(Shibasaki and Hallett,2005), which stops during sleep.

Subcortical myoclonus in the ICU is seen with intoxication, in patients with uremic (Artieda et al.,1992; Stark,1981; Tedeschi et al.,1982) or hepatic encephalopathy (Butz et al.,2014), with heatstroke-related brain injury(Bazille et al.,2005), and in association with the serotonin syndrome (Table 2), a clinical triad of 1) changes in mental-status with agitation, hypervigilance, delirium, and seizures, 2) autonomic hyperactivity with shivering, diaphoresis, mydriasis, hypertension, and tachycardia, and 3) neuromuscular abnormalities including myoclonus, tremor, hyperreflexia, clonus, and rigor(Boyer and Shannon,2005). These isolated features are unspecific, but their combination together with metabolic acidosis, rhabdomyolysis, elevated serum aminotransferase levels and creatinine, renal failure, and disseminated intravascular coagulopathy, complement the clinical picture. Subcortical myoclonus 
can also emerge in association with the posterior reversible encephalopathy syndrome(Boland et al.,2012), a rare and potentially reversible breakdown of the cerebral circulatory autoregulation(Hinchey et al.,1996), often associated with (pre)eclampsia or sever arterial hypertension, and less frequently with sepsis, GuillainBarré syndrome-related autonomic dysregulation, autoimmune connective tissue disorders, chemotherapy, and organ transplantation. Precursors include vasospasm, vasculitis, and serum hyperviscosity(Hinchey et al.,1996). Subcortical myoclonus may also emerge from subacute sclerosing panencephalitis and resembles dystonia with jerks every 4-13 seconds(Shibasaki and Hallett,2005).

Reticular reflex myoclonus, a bilateral synchronous myoclonus generated from the reticular formation of the medulla oblongata, is seen after hypoxic brain injury (Table 2). Typically, the sternocleidomastoid and trapezius muscles, and the more rostral (facial) and caudal muscles (limbs) are involved(Hallett et al.,1977).

\subsubsection{Spinal myoclonus in the ICU}

Spinal myoclonus occurs spontaneously and involves muscles innervated by spinal segments. Typically, it is stimulus insensitive and presents with irregular or pseudoperiodical repetitions at high frequencies involving flexors of the trunk, hips, and knees. In contrast, the less frequent, slowly repetitive spinal myoclonus is stimulus sensitive. In the ICU, spinal myoclonus can emerge in association with tumors(Massimi et al.,2009), trauma of spinal cord segments(Calancie,2006), with spinal/intrathecal administration of anesthesia(Zamidei et al.,2010), or with autoimmune diseases including the stiff person syndrome most commonly associated with GAD65 antibodies(Meinck et al.,1995) (Table 2). Sometimes, the involved spinal segments spread in both directions rostrally and caudally, probably conducted through propriospinal tracts(Brown et al.,1994). Spinal myoclonus also 
occurs with the stiff person syndrome plus, an autoimmune disease mediated by glycine receptor-antibodies or dipeptidyl peptidase-like protein 6(DPPX)-antibodies and characterized by progressive muscle rigidity, abnormal postures, spasms, and myoclonus(Balint et al.,2014; Carvajal-Gonzalez et al.,2014; Shugaiv et al.,2013).

\subsubsection{Peripheral myoclonus in the ICU}

Peripheral myoclonus is rare and usually caused by lesions of the plexus, nerves, roots, or rarely by anterior horn cell disease(Hudson et al.,2013) and nerve blocks(Hudson et al.,2013), possibly altering sensory inputs and inducing central reorganizations (Table 2)(Assal et al.,1998). Peripheral myoclonus is stimulus insensitive with jerks of 200 milliseconds with hemifacial spasm being the most common example.

\section{The differential diagnoses of myoclonus in the ICU}

Despite its typical phenomenology and increasing observations in critically ill patients, myoclonus can be missed or mistaken as physiologic (Table 1) or as other movement disorders seen in the ICUs such as spasms, clonus, and tremor.

\subsection{Spasms}

There is a smooth transition between myoclonus and spasms. While myoclonus is a brief and abrupt simple muscle contraction of milliseconds, spasms are more complex but stereotypic movements with fast peaks of action (milliseconds or seconds), followed by longer de-escalation phases (seconds or minutes). In contrast to myoclonus, spasms are triggered by muscle stretching or cutaneous stimulation.

\subsection{Clonus}


Clonus is an iteration or burst of triggered and maintained involuntary proprioceptive reflexes consisting of rhythmic series of muscle twitching(Wallace et al.,2005). Rhythmicity is the main feature allowing the distinction from myoclonus. Clonus is particularly associated with lesions of the upper motor neuron involving descending motor pathways, and in many cases is, accompanied by spasticity.

\subsection{Tremor}

Tremor can be misinterpreted as myoclonus as it is an involuntary rhythmic and oscillating movement(Jankovic and Fahn,1980), sometimes only detectable by EMG. Unlike myoclonus, tremor may show rhythmic episodes of alternating contractions of agonist and antagonist muscles. Sometimes myoclonus can appear to be regular which can be described as "cortical tremor".

\section{ICU-related interferences with myoclonus}

During intensive care, several factors may interfere with the typical appearance of myoclonus. Injuries of the central or peripheral nervous system and involved muscles may impede the emergence of myoclonus. Treatment-related interferences result from several drugs that are frequently used in intensive care as mentioned above (Table 2). While some anesthetics can trigger or aggravate myoclonus including etomidate (Laughlin and Newberg,1985; Lumley and Morgan,1985), propofol (Tam et al.,2009), and enflurane $(\mathrm{Ng}, 1980)$, deep anesthesia and muscle relaxants attenuate myoclonus.

Artifacts from a variety of electrical ICU-devices, including electric beds, electronic infusion devices, or pacemakers may also impede the performance and proper interpretation of electrophysiological exams. Neurophysiologic examination including 
electromyography, electroencephalography, or somatosensory evoked potentials can be limited by bandages or wounds that imped electrode placements. Potentially disturbing reversible factors need to be recognized prior to proper clinical and neurophysiological examination of myoclonus. This includes weaning the patients from interfering drugs and inactivating electrical devices not essential for immediate life-support.

\section{Electrophysiology}

\subsection{Electromyography}

Digital EMG of muscle discharges helps distinguishing myoclonus from other involuntary movements (tremor or dystonia). EMG is recorded with skin electrodes placed 2-3 cm apart overlying the muscles of interest and a simultaneous recording from several muscles to demonstrate the distribution and spread of myoclonus(Shibasaki and Hallett,2005).

Cortical myoclonus shows EMG correlates $<50$ milliseconds (Figure 1) involving agonist and antagonist muscles synchronously, whereas subcortical myoclonus exceeds 50 milliseconds. However, short EMG discharges can also be associated with brainstem reflex myoclonus(Hallett et al.,1977). In critically ill patients, positive cortical myoclonus usually occurs irregularly. Rhythmic patterns exist in non-critically ill patients seen outside the ICUs, such as familial cortical myoclonic tremor(Brown and Marsden,1996) and corticobasal degeneration(Carella et al.,1997). Negative myoclonus can be identified clinically, but EMG recorded during isometric muscle contraction helps confirming the diagnosis (Figure 1). In CJD, myoclonus can be stimulus sensitive or (more frequently) spontaneous, stimulus insensitive and pseudo-periodically in resting conditions with intervals of $600-1,500$ milliseconds(Shibasaki and Hallett,2005). 
Subcortical myoclonus, as typically seen with subacute sclerosing panencephalitis, is linked to sterotyped slow EMG discharges occurring periodically at 4-13 seconds(Shibasaki and Hallett,2005).

In spinal myoclonus, EMG should be recorded from multiple muscles to detect simultaneous contractions of muscles innervated by the same spinal segment and to uncover spreads from a certain spinal segment to rostral and/or caudal segments over $\sim 10$ meters/seconds with propriospinal myoclonus(Shibasaki and Hallett,2005). In peripheral myoclonus rhythmic contractions last 200-400 milliseconds(Assal et al.,1998).

\subsection{Electroencephalography}

Digital EEG should be recorded with electrodes over the central areas, as cortical myoclonus typically derives from the sensorimotor cortex(Shibasaki and Hallett,2005) showing multifocal or generalized spike-and-wave or poly-spike-wave discharges(Artieda et al.,1992; Baumgartner et al.,1996). In non-cortical myoclonus, jerk-linked discharges are absent.

Combined real-time EEG and EMG provide information regarding the relationship between the myoclonus and brain activities. The EEG-EMG polygraphy should be performed first, as it is the most effective, and time-efficient technique revealing involved muscle groups and correlating cortical discharges.

\subsection{Electroencephalographic-electromyographic polygraphy}

The EEG-EMG polygraph is the simultaneous recording of EEG and EMG to investigate cortical discharges that are present in cortical myoclonus (Figure 2) or absent in myoclonus with other neuroanatomical origins. This technique enables jerklocked back averaging and evoked potential studies combined with recording of the 
long-latency and long-loop reflexes(Shibasaki and Hallett,2005). Jerk-locked back averaging enables to back average the simultaneously recorded EEGs with respect to myoclonus. EMG recorded jerks should be further investigated by EEG with scalp electrodes over the respective motor-area. Usually multiple (up to 50) sweeps are recorded and superimposed to increase the contrast uncovering myoclonus-related cortical brain activity that otherwise would be missed(Shibasaki and Hallett,2005). This technique is particularly important in patients with cortical myoclonus where spikes at the central electrodes correspond somatotopically to the involved muscle. Usually, extensive electrophysiologic investigations of reticular reflex myoclonus following hypoxic brain injury with EEG-EMG-polygraphy is not performed, as evidence of structural brain damage provided by magnetic resonance imaging, absent or late N20 potentials on SSEPs, and persistent coma sufficiently proof severe brain injury and represent strong outcome predictors(Stevens and Sutter,2013). The cortical spikes identified with jerk-locked back averaging do not represent the origin of myoclonus, but the retrograde transmissions of impulses generated in the reticular formation of the brainstem.

In patients with subacute sclerosing panencephalitis the quasi-periodic myoclonus is linked to high-amplitude (200-600 uV), long-duration (500-2000 milliseconds) EEG ("Radermacker")-complexes which are pathognomonic for the disease together with the long discharge interval of 4-13 seconds(Celesia,1973; Praveen-kumar et al.,2007).

\subsection{Somatosensory evoked potentials}

For SSEPs, the median nerve is stimulated at the wrist with square-wave impulses of 0.2-0.5 milliseconds at $1-2 \mathrm{~Hz}$ with $10-15 \%$ above the motor threshold. Sometimes, with cortical reflex myoclonus, identification of the motor threshold is difficult by visual 
inspection because of significantly lowered threshold of the long-latency reflex that may obscure the direct motor response. Long-loop reflexes are automatic motor responses to somatosensory stimuli that are believed to operate via the cerebral cortex ("transcortical reflexes"). However, long-loop reflexes occur at latencies too long to be explained with the mediation by segmental spinal cord circuits yet too short to be clearly mediated volitionally.

SSEPs of cortical reflex myoclonus show waveforms with enlarged early cortical components(Shibasaki and Hallett,2005). These pathognomonic "giant" potentials (10 times as large as normal(Hitomi et al.,2006), or >10 uV with medianus-SSEP P25-N35) can be distinguished and support the clinical diagnosis of cortical or cortical reflex myoclonus.

The short-latency SSEP components, which occur subcortically before 20 milliseconds, are not enhanced in any type of myoclonus. Hence, the differentiation of subcortical from other types of myoclonus is not possible by SSEP(Shibasaki and Hallett,2005).

In reticular reflex myoclonus after hypoxic brain injury, the long-latency reflex, which is thought to be mediated by the spinal cord, is enhanced, but not cortical evoked potentials. However, there is a great inter-individual variability of reflex latency, indicating the necessity for looking at individual responses to a single stimulus rather than averaging(Shibasaki and Hallett,2005).

\section{Neuroimaging}

Although there is no specific neuroimaging correlate of myoclonus, brain imaging should be performed to exclude or identify imaging patterns related to underlying diseases. In the following section we will limit our review on data from magnetic resonance imaging (MRI), as computed tomography does not reveal specific 
changes in most cases. Other neuroimaging techniques, such as magnetic resonance spectroscopy, positron emission tomography, and single photon emission computed tomography are not well studied.

The diagnostic yield of neuroimaging is studied best in adult patients with hypoxic brain injury following cardiac arrest (Table 5) with multifocal cortical or white matter changes on brain MRI (Figure 3).

In patients with prolonged status epilepticus, brain MRI may also reveal hyperintensities mainly restricted to the seizing cortical areas and subcortical grey matter that may resemble changes from hypoxic brain injury(Cartagena et al.,2014; Cianfoni et al.,2013).

In myoclonus from encephalitides, only few cases are described in the literature. The MRI can show a variety of abnormalities that depend on the underlying cause of encephalitis. Patients with myoclonus emerging with Herpes Simplex virus encephalitis may show hyperintensities with slight edema in the bilateral temporal and insular cortices and right thalamus on the T2-weighted and fluid attenuation inversion recovery (FLAIR) images of brain MRI(Park et al.,2011). In patients with Epstein-Barr virus meningo-encephalitis that presented with pharmacoresistent myoclonus, the MRI showed a high signal in the leptomeninges, especially in the bilateral parietal sulci(Lee et al.,2014). However, in patients with West Nile virus encephalitis induced opsoclonus-myoclonus syndrome(Cooper and Said,2014) and patients with opsoclonus-myoclonus syndrome associated with mumps virus infection(Kang and Kim,2014), the MRI is mostly normal. In patients with myoclonus from subacute sclerosing panencehalitis, brain MRI revealed punctuate hyperintensities in subcortical and periventricular deep white matter in both cerebral hemispheres(Sharma and Biswas,2013). MRI studies in patients with HIV-related opsoclonus-myoclonus-ataxia syndromes does not reveal significant 
abnormalities(Kanjanasut et al.,2010).

Aside from neuroimaging studies in patients with infectious encephalitides, several cases have been reported of patients with paraneoplastic encephalitis presenting with opsoclonus-myoclonus-like syndrome and stiff-person syndrome. However, brain MRI is mostly reported to be normal(Kumar et al.,2005; Mukherjee et al.,2004; Thumen and Moser,2010) and only few cases note multiple nonspecific nonenhancing areas of signal abnormality involving the cortex of both cerebral hemispheres(Rickman et al.,2000). While brain MRI in encephalomyelitis with rigidity and myoclonus (PERM) can reveal numerous small foci of high T2 FLAIR in the subcortical, deep and periventricular white matter of the cerebral hemispheres bilaterally(Kyskan et al.,2013), other cases are reported without abnormalities on neuroimaging(Kraemer and Berlit,2008; Spitz et al.,2004). MRI of the spine did not demonstrate any significant abnormalities. In another case with an anti-ri-antibodyassociated paraneoplastic syndrome in a man with breast cancer, the brain MRI showed a reversible pontine lesion(Kim et al.,2009).

In steroid responsive encephalitis with autoimmune thyroiditis, MRI abnormalities and myoclonus were seen in a study of 80 patients(Yoneda,2012).

Neuroimaging studies in patients with myoclonus associated with metabolic derangements are rare. Although changes on brain MRI in patients with uremia or liver failure are well described, our search of the literature could not find any reports of brain MRI findings in this context.

Rarely, patients are reported to present with opsoclonus-myoclonus syndrome showing signs of a posterior reversible encephalopathy syndrome on brain MRI(Boland et al.,2012) (Figure 4). 


\section{Treatment of myoclonus in the ICU}

In multifocal cortical myoclonus, treatment of the underlying disease is most effective. In patients with multiple drugs, the discontinuation of medication and treatment of metabolic derangements may resolve myoclonus. In most critically ill patients, however, myoclonus persists and may harm the patients. Before antimyoclonic treatment is started, fixation of extremities or medical devices to the body is needed, as abrupt movements may accidently pull out intravenous lines or endotracheal tubes.

Treatment of symptomatic myoclonus is challenging. Often high drug doses are needed that can frequently lead to side-effects. Drugs that are effective in some patients may worsen symptoms in others. Because of the low level of evidence, therapeutic options rely on expert opinions(Dijk and Tijssen,2010). Although some drugs have limited effects, they may be more efficient when combined with drugs acting on different pathways. Figure 5 summarizes treatment options for the different types of myoclonus.

\subsection{Treatment of cortical myoclonus}

Cortical myoclonus responds well to antiepileptic drugs. Levetiracetam is recommended as first-line treatment and additional high dosed piracetam may have antimyoclonic effects. However, the latter is not available in many countries including North America. Valproic acid is recommended as second-line medication. These drugs are recommended not only because of their antimyoclonic effects, but also because they do not significantly alter consciousness. If sedating effects are not critical or patients are mechanically ventilated, benzodiazepines may be titrated until antimyoclonic effect is reached. In posthypoxic cortical reflex myoclonus, clonazepam and valproic acid were recommended before levetiracetam became 
broadly available(Obeso et al.,1989). Mostly, a combination of drugs is needed for successful treatment. In a study of patients with Lance-Adams syndrome clonazepam, valproate, and piracetam were effective in treating approximately half of the patients(Frucht and Fahn,2000). Other opinion leaders recommend levetiracetam, zonisamide, clonazepam, and valproate as the first treatments of choice(Polesin and Stern,2006).

\subsection{Treatment of subcortical myoclonus}

Antiepileptic drugs are mostly ineffective. Brainstem myoclonus is often treatable with clonazepam(Tijssen et al.,1997a), and L-5-hydroxytryptophan can be effective for reticular reflex myoclonus(Obeso,1995).

In the opsoclonus-myoclonus syndrome, treatment of the underlying disease with rituximab, adrenocorticotropic hormones, or intravenous immunoglobulin therapy is recommended(Dijk and Tijssen,2010) if not intoxication-related. In myoclonus dystonia, clonazepam and trihexyphenidyl can be effective. In addition L-5-hydroxytryptophan (a serotonin precursor) is recommended, but side-effects are frequent. To prevent conversion to serotonin, L-5-hydroxytryptophan should be used with a decarboxylase inhibitor, which might limit side-effects(Dijk and Tijssen,2010). However, L-5-hydroxytryptophan is not available in many countries. Alternatively, sodium oxybate, levodopa, zolpidem, levetiracetam, piracetam, and deep brain stimulation of the globus pallidus interna are reported to be effective(Gerschlager and Brown,2009).

\subsection{Treatment of spinal myoclonus}

Treatment of the underlying cause is crucial, as symptomatic therapy is often disappointing. With propriospinal myoclonus many patients have psychogenic 
myoclonus calling for psychiatric intervention(van der Salm et al.,2014) together with clonazepam as the first-line drug for segmental and propriospinal myoclonus. Alternatively, zonisamide can be effective for propriospinal myoclonus(Dijk and Tijssen,2010).

\subsection{Treatment of peripheral myoclonus}

Pharmacological treatment is mostly disappointing, but botulinum toxin may be effective, especially for hemifacial spasm(Dijk and Tijssen,2010).

\section{Conclusions}

Myoclonus can emerge with many critical illnesses, but may resemble physiologic and other pathologic involuntary movements. Central or peripheral neurologic injuries, anesthetics, and muscle relaxants interfere with the typical appearance of myoclonus. Identifying "real myoclonus" in critically ill patients, determining the neuroanatomical origin, and distinguishing between myoclonus associated with critical and non-critical illnesses is essential to direct adequate treatment. The recognition of cortical myoclonus is critical, as this myoclonus is treatable and may progresses to generalized convulsive seizures or status epilepticus regardless of etiologies. However, the neuroanatomical origins and pathophysiological mechanisms cannot be reliably determined by clinical observation alone calling for heightened awareness and a rigorous use of neurophysiological and neuroimaging examinations.

The combination of clinical, electrophysiological and neuroradiological examinations reliably uncovers the neuroanatomical sources and pathophysiological mechanisms of myoclonus. 


\section{References}

Al Thenayan E, Savard M, Sharpe M, Norton L, and Young B. Predictors of poor neurologic outcome after induced mild hypothermia following cardiac arrest. Neurology 2008;71:15351537.

Algahtani HA, Aldarmahi AA, Al-Rabia MW, Almalki WH, and Bryan Young G. Generalized myoclonus and spasticity induced by lamotrigine toxicity: a case report and literature review. Clin Neuropharmacol 2014;37:52-54.

Artieda J, Muruzabal J, Larumbe R, Garcia de Casasola C, and Obeso JA. Cortical mechanisms mediating asterixis. Mov Disord 1992;7:209-216.

Assal F, Magistris MR, and Vingerhoets FJ. Post-traumatic stimulus suppressible myoclonus of peripheral origin. J Neurol Neurosurg Psychiatry 1998;64:673-675.

Babul N, and Darke AC. Putative role of hydromorphone metabolites in myoclonus. Pain 1992;51:260-261.

Bakker MJ, van Dijk JG, van den Maagdenberg AM, and Tijssen MA. Startle syndromes. Lancet Neurol 2006;5:513-524.

Balint B, Jarius S, Nagel S, Haberkorn U, Probst C, Blocker IM, Bahtz R, Komorowski L, Stocker W, Kastrup A, Kuthe M, and Meinck HM. Progressive encephalomyelitis with rigidity and myoclonus: a new variant with DPPX antibodies. Neurology 2014;82:1521-1528.

Balint B, Regula JU, Jarius S, and Wildemann B. Caspr2 antibodies in limbic encephalitis with cerebellar ataxia, dyskinesias and myoclonus. J Neurol Sci 2013;327:73-74.

Bandelot JB, and Mihout B. [Myoclonic encephalopathy due to diclofenac]. Nouv Presse Med 1978;7:1406.

Baumgartner C, Podreka I, Olbrich A, Novak K, Serles W, Aull S, Almer G, Lurger S, Pietrzyk U, Prayer D, and Lindinger G. Epileptic negative myoclonus: An EEG-single-photon emission CT study indicating involvement of premotor cortex. Neurology 1996;46:753-758. 
Bazille C, Megarbane B, Bensimhon D, Lavergne-Slove A, Baglin AC, Loirat P, Woimant F, Mikol J, and Gray F. Brain damage after heat stroke. J Neuropathol Exp Neurol 2005;64:970975.

Belcastro V, Arnaboldi M, Taborelli A, and Prontera P. Induction of epileptic negative myoclonus by addition of lacosamide to carbamazepine. Epilepsy Behav 2011;20:589-590. Benbadis SR, Chen S, and Melo M. What's shaking in the ICU? The differential diagnosis of seizures in the intensive care setting. Epilepsia 2010;51:2338-2340.

Berger $\mathrm{C}$, and Meinck HM. Head retraction reflex in stiff-man syndrome and related disorders. Mov Disord 2003;18:906-911.

Berger JR, and Mehari E. Paraneoplastic opsoclonus-myoclonus secondary to malignant melanoma. J Neurooncol 1999;41:43-45.

Berkovic SF, So NK, and Andermann F. Progressive myoclonus epilepsies: clinical and neurophysiological diagnosis. J Clin Neurophysiol 1991;8:261-274.

Binelli S, Agazzi P, Canafoglia L, Scaioli V, Panzica F, Visani E, Di Fede G, Giaccone G, Bizzi A, Bugiani O, Avanzini G, Tagliavini F, and Franceschetti S. Myoclonus in CreutzfeldtJakob disease: polygraphic and video-electroencephalography assessment of 109 patients. Mov Disord 2010;25:2818-2827.

Birbamer G, Gerstenbrand F, Kofler M, Buchberger W, Felber S, and Aichner F. Posttraumatic segmental myoclonus associated with bilateral olivary hypertrophy. Acta Neurol Scand 1993;87:505-509.

Birlutiu V, and Birlutiu RM. Opsoclonus-myoclonus syndrome attributable to West Nile encephalitis: a case report. J Med Case Rep 2014;8:232.

Boland T, Strause J, Hu M, Santamaria D, Liang TW, Kremens D, Sergott R, and Moussouttas M. Posterior Reversible Encephalopathy Syndrome Presenting as OpsoclonusMyoclonus. Neuroophthalmology 2012;36:149-152.

Boyer EW, and Shannon M. The serotonin syndrome. N Engl J Med 2005;352:1112-1120. Brown $\mathrm{P}$, and Marsden CD. Rhythmic cortical and muscle discharge in cortical myoclonus. Brain 1996;119:1307-1316. 
Brown P, Rothwell JC, Thompson PD, and Marsden CD. Propriospinal myoclonus: evidence for spinal "pattern" generators in humans. Mov Disord 1994;9:571-576.

Buchman AS, Bennett DA, and Goetz CG. Bromocriptine-induced myoclonus. Neurology $1987 ; 37: 885$

Butz M, Timmermann L, Gross J, Pollok B, Sudmeyer M, Kircheis G, Haussinger D, and Schnitzler A. Cortical activation associated with asterixis in manifest hepatic encephalopathy. Acta Neurol Scand 2014;130:260-267.

Calancie B. Spinal myoclonus after spinal cord injury. J Spinal Cord Med 2006;29:413-424. Canafoglia L, Panzica F, Franceschetti S, Carriero MR, Ciano C, Scaioli V, Chiapparini L, Visani E, and Avanzini G. Rhythmic cortical myoclonus in a case of HIV-related encephalopathy. Mov Disord 2003;18:1533-1538.

Carella F, Ciano C, Panzica F, and Scaioli V. Myoclonus in corticobasal degeneration. Mov Disord 1997;12:598-603.

Cartagena AM, Young GB, Lee DH, and Mirsattari SM. Reversible and irreversible cranial MRI findings associated with status epilepticus. Epilepsy Behav 2014;33:24-30.

Carvajal-Gonzalez A, Leite MI, Waters P, Woodhall M, Coutinho E, Balint B, Lang B, Pettingill P, Carr A, Sheerin UM, Press R, Lunn MP, Lim M, Maddison P, Meinck HM, Vandenberghe W, and Vincent A. Glycine receptor antibodies in PERM and related syndromes: characteristics, clinical features and outcomes. Brain 2014;137:2178-2192. Caviness JN, and Evidente VG. Cortical myoclonus during lithium exposure. Arch Neurol 2003;60:401-404.

Celesia GG. Pathophysiology of periodic EEG complexes in subacute sclerosing panencehalitis (SSPE). Electroencephalogr Clin Neurophysiol 1973;35:293-300. Centers of Disease Control and Prevention. Creutzfeldt-Jakob Disease, Classic (CJD) http://www.cdc.gov/prions/cjd/index.html [last accessed: June 2015, 2015]. Chen JC, Hsu YT, Chiou TS, Lu MK, Lin YC, Kao CH, Huang WS, and Tsai CH. Cortical and non-cortical myoclonus of Creutzfeldt-Jakob disease. Eur Neurol 2010;64:265-267. 
Choi SP, Park KN, Park HK, Kim JY, Youn CS, Ahn KJ, and Yim HW. Diffusion-weighted magnetic resonance imaging for predicting the clinical outcome of comatose survivors after cardiac arrest: a cohort study. Crit Care 2010;14:R17.

Chua TP, Farrell T, and Lipkin DP. Myoclonus associated with propafenone. BMJ 1994;308:113.

Cianfoni A, Caulo M, Cerase A, Della Marca G, Falcone C, Di Lella GM, Gaudino S, Edwards J, and Colosimo C. Seizure-induced brain lesions: a wide spectrum of variably reversible MRI abnormalities. Eur J Radiol 2013;82:1964-1972.

Cooper CJ, and Said S. West nile virus encephalitis induced opsoclonus-myoclonus syndrome. Neurol Int 2014;6:5359.

Cronberg T, Rundgren M, Westhall E, Englund E, Siemund R, Rosen I, Widner H, and Friberg $\mathrm{H}$. Neuron-specific enolase correlates with other prognostic markers after cardiac arrest. Neurology 2011;77:623-630.

DeFelipe-Mimbrera A, Masjuan J, Corral I, Villar LM, Graus F, and Garcia-Barragan N. Opsoclonus-myoclonus syndrome and limbic encephalitis associated with GABAB receptor antibodies in CSF. J Neuroimmunol 2014;272:91-93.

Denison DJ, and Alghzaly AA. Busulfan induced myoclonus. Saudi Med J 2006;27:557-558. Deuschl G, Toro C, Valls-Sole J, Zeffiro T, Zee DS, and Hallett M. Symptomatic and essential palatal tremor. 1. Clinical, physiological and MRI analysis. Brain 1994;117:775-788. Dijk JM, and Tijssen MA. Management of patients with myoclonus: available therapies and the need for an evidence-based approach. Lancet Neurol 2010;9:1028-1036.

Drake ME, Jr. Recurrent spontaneous myoclonus in alcohol withdrawal. South Med J 1983;76:1040-1042.

Duarte J, Sempere AP, Cabezas MC, Marcos J, and Claveria LE. Postural myoclonus induced by phenytoin. Clin Neuropharmacol 1996;19:536-538.

Ege F, Kocak Y, Titiz AP, Ozturk SM, Ozturk S, and Ozbakir S. Gabapentin-Induced myoclonus: case report. Mov Disord 2008;23:1947-1948. 
English WA, Giffin NJ, and Nolan JP. Myoclonus after cardiac arrest: pitfalls in diagnosis and prognosis. Anaesthesia 2009;64:908-911.

Evidente VG, and Caviness JN. Focal cortical transient preceding myoclonus during lithium and tricyclic antidepressant therapy. Neurology 1999;52:211-213.

Fahn S. Overview, history and classifi cation of myoclonus. In: Myoclonus and paroxysmal dyskinesias, edited by Fahn S, Frucht S, Hallet M, and Truong D. Philadelphia: Lippincot Williams \& Wilkins, 2002, p. 13-17.

Fahn S, Marsden CD, and Van Woert MH. Definition and classification of myoclonus. Adv Neurol 1986;43:1-5.

Fanella M, Egeo G, Fattouch J, Casciato S, Lapenta L, Morano A, Giallonardo AT, and Di Bonaventura C. Oxcarbazepine-induced myoclonic status epilepticus in juvenile myoclonic epilepsy. Epileptic Disord 2013;15:181-187.

Fernandez-Torre JL, and Diaz-Castroverde AG. Non-convulsive status epilepticus in elderly individuals: report of four representative cases. Age Ageing 2004;33:78-81.

Frucht S, and Eidelberg D. Imipenem-induced myoclonus. Mov Disord 1997;12:621-622. Frucht S, and Fahn S. The clinical spectrum of posthypoxic myoclonus. Mov Disord 2000;15 Suppl 1:2-7.

Frucht SJ, Trost M, Ma Y, and Eidelberg D. The metabolic topography of posthypoxic myoclonus. Neurology 2004;62:1879-1881.

Fugate JE, Kalimullah EA, Hocker SE, Clark SL, Wijdicks EF, and Rabinstein AA. Cefepime neurotoxicity in the intensive care unit: a cause of severe, underappreciated encephalopathy. Crit Care 2013;17:R264.

Fugate JE, Wijdicks EF, Mandrekar J, Claassen DO, Manno EM, White RD, Bell MR, and Rabinstein AA. Predictors of neurologic outcome in hypothermia after cardiac arrest. Ann Neurol 2010;68:907-914.

Gardner TM, Aziz R, Muralee S, and Tampi RR. Valproic Acid-induced myoclonus in a demented patient: a case report. Case Rep Med 2009;2009:392091.

Gerschlager W, and Brown P. Myoclonus. Curr Opin Neurol 2009;22:414-418. 
Ghoreishi E, Shahidi GA, Rohani M, Nabavi M, Aghaei M, and Akhoundi FH. PalatalMyoclonus as a Presentation of Hashimoto Encephalopathy: an interesting case report. Iran J Psychiatry 2013;8:149-151.

Hallett M, Chadwick D, Adam J, and Marsden CD. Reticular reflex myoclonus: a physiological type of human post-hypoxic myoclonus. J Neurol Neurosurg Psychiatry 1977;40:253-264.

Hansen KS, and Sharp FR. Gasoline sniffing, lead poisoning, and myoclonus. JAMA 1978;240:1375-1376.

Healy DG, Ingle GT, and Brown P. Pregabalin- and gabapentin-associated myoclonus in a patient with chronic renal failure. Mov Disord 2009;24:2028-2029.

Hellwig S, and Amtage F. Pregabalin-induced cortical negative myoclonus in a patient with neuropathic pain. Epilepsy Behav 2008;13:418-420.

Hinchey J, Chaves C, Appignani B, Breen J, Pao L, Wang A, Pessin MS, Lamy C, Mas JL, and Caplan LR. A reversible posterior leukoencephalopathy syndrome. N Engl J Med 1996;334:494-500.

Hitomi T, Ikeda A, Matsumoto R, Kinoshita M, Taki J, Usui K, Mikuni N, Nagamine T, Hashimoto N, Shibasaki H, and Takahashi R. Generators and temporal succession of giant somatosensory evoked potentials in cortical reflex myoclonus: epicortical recording from sensorimotor cortex. Clin Neurophysiol 2006;117:1481-1486.

Howard RS, Holmes PA, Siddiqui A, Treacher D, Tsiropoulos I, and Koutroumanidis M. Hypoxic-ischaemic brain injury: imaging and neurophysiology abnormalities related to outcome. QJM 2012;105:551-561.

Hudson AJ, Guthmiller KB, and Hyatt MN. Myoclonus following a Peripheral Nerve Block. Case Rep Anesthesiol 2013;2013:213472.

Irioka T, Machida A, Yokota T, and Mizusawa H. Antihistamine-associated myoclonus: A case report. Mov Disord 2008;23:1615-1616.

Jacob PC, and Chand RP. A posttraumatic thalamic lesion associated with contralateral action myoclonus. Mov Disord 1999;14:512-514. 
Jankovic J, and Fahn S. Physiologic and pathologic tremors. Diagnosis, mechanism, and management. Ann Intern Med 1980;93:460-465.

Jayathissa S, Woolley M, Ganasegaram M, Holden J, and Cu E. Myoclonus and delirium associated with ciprofloxacin. Age Ageing 2010;39:762.

Jeret JS. Diltiazem-induced myoclonus. Neurology 2002;59:962; author reply 962.

Kang $\mathrm{BH}$, and Kim Jl. Opsoclonus-myoclonus syndrome associated with mumps virus infection. J Clin Neurol 2014;10:272-275.

Kanjanasut N, Phanthumchinda K, and Bhidayasiri R. HIV-related opsoclonus-myoclonusataxia syndrome: report on two cases. Clin Neurol Neurosurg 2010;112:572-574.

Kim H, Lim Y, and Kim KK. Anti-ri-antibody-associated paraneoplastic syndrome in a man with breast cancer showing a reversible pontine lesion on MRI. J Clin Neurol 2009;5:151152.

Kompf D, and Neundorfer B. [Neurotoxic side effects of piperazine in adults. Epileptic twilight state with myoclonia (author's transl)]. Arch Psychiatr Nervenkr 1974;218:223-233.

Kraemer M, and Berlit P. Progressive encephalomyelitis with rigidity and myoclonus in an 81year-old patient. Clin Neurol Neurosurg 2008;110:279-281.

Kumar A, Lajara-Nanson WA, and Neilson RW, Jr. Paraneoplastic Opsoclonus-Myoclonus Syndrome: initial presentation of non-Hodgkins lymphoma. J Neurooncol 2005;73:43-45. Kyskan R, Chapman K, Mattman A, and Sin D. Antiglycine receptor antibody and encephalomyelitis with rigidity and myoclonus (PERM) related to small cell lung cancer. BMJ Case Rep 2013;2013:

Lance JW, and Adams RD. The syndrome of intention or action myoclonus as a sequel to hypoxic encephalopathy. Brain 1963;86:111-136.

Laughlin TP, and Newberg LA. Prolonged myoclonus after etomidate anesthesia. Anesth Analg 1985;64:80-82.

Lee CY, Cheng SJ, and Chou CL. Myoclonus as the main presentation of Epstein-Barr virus encephalitis. Acta Neurol Belg 2014; 
Leigh PN, Rothwell JC, Traub M, and Marsden CD. A patient with reflex myoclonus and muscle rigidity: "jerking stiff-man syndrome". J Neurol Neurosurg Psychiatry 1980;43:11251131.

Lempert T, Bauer M, and Schmidt D. Syncope: a videometric analysis of 56 episodes of transient cerebral hypoxia. Ann Neurol 1994;36:233-237.

Lim EC, Tan JJ, Ong BK, and Wilder-Smith EP. Generalised myoclonus evolving into epilepsia partialis continua due to a cingulate gyrus lesion: case report and review of the literature. Parkinsonism Relat Disord 2004;10:447-449.

Lozsadi DA, Forster A, and Fletcher NA. Cannabis-induced propriospinal myoclonus. Mov Disord 2004;19:708-709.

Lumley J, and Morgan M. Myoclonus after etomidate anesthesia. Anesth Analg 1985;64:1034.

Magaudda A, and Di Rosa G. Carbamazepine-induced non-epileptic myoclonus and tic-like movements. Epileptic Disord 2012;14:172-173.

Massimi L, Battaglia D, Paternoster G, Martinelli D, Sturiale C, and Di Rocco C. Segmental spinal myoclonus and metastatic cervical ganglioglioma: an unusual association. J Child Neurol 2009;24:365-369.

Meinck HM, Ricker K, Hulser PJ, and Solimena M. Stiff man syndrome: neurophysiological findings in eight patients. J Neurol 1995;242:134-142.

Meletti S, Tinuper P, Bisulli F, and Santucci M. Epileptic negative myoclonus and brief asymmetric tonic seizures. A supplementary sensorimotor area involvement for both negative and positive motor phenomena. Epileptic Disord 2000;2:163-168.

Miller AD, Prost VM, Bookstaver PB, and Gaines KJ. Topiramate-induced myoclonus and psychosis during migraine prophylaxis. Am J Health Syst Pharm 2010;67:1178-1180. Monday K, and Jankovic J. Psychogenic myoclonus. Neurology 1993;43:349-352. Morales La Madrid A, Rubin CM, Kohrman M, Pytel P, and Cohn SL. Opsoclonus-myoclonus and anti-Hu positive limbic encephalitis in a patient with neuroblastoma. Pediatr Blood Cancer 2012;58:472-474. 
Mukherjee A, Mukherjee A, and Chakrabarty S. A case of opsoclonus-myoclonus-ataxia with neuroblastoma. J Indian Med Assoc 2004;102:647-648.

Nardocci N. Myoclonus-dystonia syndrome. Handb Clin Neurol 2011;100:563-575.

$\mathrm{Ng} \mathrm{AT.} \mathrm{Prolonged} \mathrm{myoclonic} \mathrm{contractions} \mathrm{after} \mathrm{enflurane} \mathrm{anaesthesia} \mathrm{-} \mathrm{a} \mathrm{case} \mathrm{report.} \mathrm{Can}$ Anaesth Soc J 1980;27:502-503.

Obeso JA. Therapy of myoclonus. Clin Neurosci 1995;3:253-257.

Obeso JA, Artieda J, Rothwell JC, Day B, Thompson P, and Marsden CD. The treatment of severe action myoclonus. Brain 1989;112:765-777.

Obeso JA, Rothwell JC, and Marsden CD. The spectrum of cortical myoclonus. From focal reflex jerks to spontaneous motor epilepsy. Brain 1985;108:193-124.

Ono K, Komai K, and Yamada M. Myoclonic involuntary movement associated with chronic manganese poisoning. J Neurol Sci 2002;199:93-96.

Park JM, Park JS, Kim YW, Lee HW, Lee DI, Park SP, and Song HS. Unilateral negative myoclonus caused by herpes simplex virus encephalitis. J Mov Disord 2011;4:49-52. Park JS, Lee SW, Kim H, Min JH, Kang JH, Yi KS, Park KH, and Lee BK. Efficacy of diffusion-weighted magnetic resonance imaging performed before therapeutic hypothermia in predicting clinical outcome in comatose cardiopulmonary arrest survivors. Resuscitation 2015;88:132-137.

Patel S, Roshan VR, Lee KC, and Cheung RJ. A myoclonic reaction with low-dose hydromorphone. Ann Pharmacother 2006;40:2068-2070.

Pedavally S, Fugate JE, and Rabinstein AA. Serotonin syndrome in the intensive care unit: clinical presentations and precipitating medications. Neurocrit Care 2014;21:108-113. Polesin A, and Stern M. Post-anoxic myoclonus: a case presentation and review of management in the rehabilitation setting. Brain Inj 2006;20:213-217. Potter JM, Reid DB, Shaw RJ, Hackett P, and Hickman PE. Myoclonus associated with treatment with high doses of morphine: the role of supplemental drugs. BMJ 1989;299:150153. 
Praharaj SK, Venkatesh BG, Sarkhel S, Zia-ul-Haq M, and Sinha VK. Clozapine-induced myoclonus: a case study and brief review. Prog Neuropsychopharmacol Biol Psychiatry 2010;34:242-243.

Praveen-kumar S, Sinha S, Taly AB, Jayasree S, Ravi V, Vijayan J, and Ravishankar S. Electroencephalographic and imaging profile in a subacute sclerosing panencephalitis (SSPE) cohort: a correlative study. Clin Neurophysiol 2007;118:1947-1954.

Rickman OB, Parisi JE, Yu Z, Lennon VA, and Vernino S. Fulminant autoimmune cortical encephalitis associated with thymoma treated with plasma exchange. Mayo Clin Proc 2000;75:1321-1326.

Rossetti AO, Carrera E, and Oddo M. Early EEG correlates of neuronal injury after brain anoxia. Neurology 2012;78:796-802.

Rossetti AO, Oddo M, Logroscino G, and Kaplan PW. Prognostication after cardiac arrest and hypothermia: A prospective study. Ann Neurol 2010;5:161-174.

Rubboli G, Parmeggiani L, and Tassinari CA. Frontal inhibitory spike component associated with epileptic negative myoclonus. Electroencephalogr Clin Neurophysiol 1995;95:201-205. Russo LS, Beale G, Sandroni S, and Ballinger WE. Aluminium intoxication in undialysed adults with chronic renal failure. J Neurol Neurosurg Psychiatry 1992;55:697-700.

Sackellares JC, and Smith DB. Myoclonus with electrocerebral silence in a patient receiving penicillin. Arch Neurol 1979;36:857-858.

Sandyk R. Head retraction reflex and parkinsonism--a preliminary study. S Afr Med J 1982;61:105-106.

Sarva H, and Panichpisal K. Gentamicin-induced myoclonus: a case report and literature review of antibiotics-induced myoclonus. Neurologist 2012;18:385-388.

Savica R, Rabinstein AA, and Josephs KA. Ifosfamide associated myoclonusencephalopathy syndrome. J Neurol 2011;258:1729-1731.

Scharf D. Opsoclonus-myoclonus following the intranasal usage of cocaine. J Neurol Neurosurg Psychiatry 1989;52:1447-1448. 
Seder DB, Sunde K, Rubertsson S, Mooney M, Stammet P, Riker RR, Kern KB, Unger B, Cronberg T, Dziodzio J, Nielsen N, and International Cardiac Arrest R. Neurologic outcomes and postresuscitation care of patients with myoclonus following cardiac arrest. Crit Care Med 2015;43:965-972.

Sharma V, and Biswas D. Steroid-responsive myoclonus in adult-onset subacute sclerosing panencephalitis. J Neuropsychiatry Clin Neurosci 2013;25:E30-32.

Shibasaki H. Myoclonus and startle syndromes. In: Parkinson's disease and movement disorders, edited by Jankovic JJ, and Tolosa E. Philadelphia: Lippincott, Williams \& Wilkins, 2002, p. 291-209.

Shibasaki H. Pathophysiology of negative myoclonus and asterixis. Adv Neurol 1995;67:199209.

Shibasaki $\mathrm{H}$, and Hallett M. Electrophysiological studies of myoclonus. Muscle Nerve 2005;31:157-174.

Shugaiv E, Leite MI, Sehitoglu E, Woodhall M, Cavus F, Waters P, Icoz S, Birisik O, Ugurel E, Ulusoy C, Kurtuncu M, Vural B, Vincent A, Akman-Demir G, and Tuzun E. Progressive encephalomyelitis with rigidity and myoclonus: a syndrome with diverse clinical features and antibody responses. Eur Neurol 2013;69:257-262.

Smith JH, Dhamija R, Moseley BD, Sandroni P, Lucchinetti CF, Lennon VA, and Kantarci $\mathrm{OH} . \mathrm{N}$-methyl-D-aspartate receptor autoimmune encephalitis presenting with opsoclonusmyoclonus: treatment response to plasmapheresis. Arch Neurol 2011;68:1069-1072.

Song IU, Lee DG, Kim JS, An JY, Lee SB, Kim YI, and Lee KS. Unilateral epileptic negative myoclonus following focal lesion of the postcentral cerebral cortex due to acute middle cerebral infarction. J Clin Neurol 2006;2:272-275.

Spitz M, Ferraz HB, Barsottini OG, and Gabbai AA. Progressive encephalomyelitis with rigidity: a paraneoplastic presentation of oat cell carcinoma of the lung. Case report. Arq Neuropsiquiatr 2004;62:547-549.

Stark RJ. Reversible myoclonus with uraemia. Br Med J (Clin Res Ed) 1981;282:1119-1120. 
Stern WM, Howard R, Chalmers RM, Woodhall MR, Waters P, Vincent A, and

Wickremaratchi MM. Glycine receptor antibody mediated Progressive Encephalomyelitis with Rigidity and Myoclonus (PERM): a rare but treatable neurological syndrome. Pract Neurol 2014;14:123-127.

Stevens RD, and Sutter R. Prognosis in severe brain injury. Crit Care Med 2013;41:11041123.

Strachan PM, and Benoff BA. Mental status change, myoclonus, electrocardiographic changes, and acute respiratory distress syndrome induced by quetiapine overdose. Pharmacotherapy 2006;26:578-582.

Stuerenburg HJ, Claassen J, Eggers C, and Hansen HC. Acute adverse reaction to fentanyl in a 55 year old man. J Neurol Neurosurg Psychiatry 2000;69:281-282.

Sutter R, Rüegg S, and Kaplan PW. Epidemiology, diagnosis, and management of nonconvulsive status epilepticus_Opening Pandora's box. Neurology Clin Pract 2012;2:275286.

Tam MK, Irwin MG, Tse ML, Lui YW, Law KI, and Ng PW. Prolonged myoclonus after a single bolus dose of propofol. Anaesthesia 2009;64:1254-1257.

Tassinari CA, Rubboli G, Parmeggiani L, Valzania F, Plasmati R, Riguzzi P, Michelucci R, Volpi L, Passarelli D, Meletti S, et al. Epileptic negative myoclonus. Adv Neurol 1995;67:181197.

Tedeschi F, Trabattoni G, Tagliavini F, and Lechi A. Encephalopathy with myoclonus in an uremic non dialysed patient. A case report. Acta Neurol (Napoli) 1982;4:129-134.

Teepker M, Hamer HM, Knake S, Bandmann O, Oertel WH, and Rosenow F. Myoclonic encephalopathy caused by chronic bismuth abuse. Epileptic Disord 2002;4:229-233.

Thumen A, and Moser A. An uncommon paraneoplastic Ri-positive opsoclonus-myoclonuslike syndrome and stiff-person syndrome with elevated glutamate/GABA ratio in the cerebrospinal fluid after breast cancer. J Neurol 2010;257:1215-1217.

Tijssen MA, Schoemaker HC, Edelbroek PJ, Roos RA, Cohen AF, and van Dijk JG. The effects of clonazepam and vigabatrin in hyperekplexia. J Neurol Sci 1997a;149:63-67. 
Tijssen MA, Voorkamp LM, Padberg GW, and van Dijk JG. Startle responses in hereditary hyperekplexia. Arch Neurol 1997b;54:388-393.

Topcuoglu MA, Oguz KK, Buyukserbetci G, and Bulut E. Prognostic value of magnetic resonance imaging in post-resuscitation encephalopathy. Intern Med 2009;48:1635-1645. Uehara T, Murai H, Yamasaki R, Kikuchi H, Shigeto H, Ohyagi Y, and Kira J. Thymomaassociated progressive encephalomyelitis with rigidity and myoclonus successfully treated with thymectomy and intravenous immunoglobulin. Eur Neurol 2011;66:328-330.

van der Salm SM, Erro R, Cordivari C, Edwards MJ, Koelman JH, van den Ende T, Bhatia KP, van Rootselaar AF, Brown P, and Tijssen MA. Propriospinal myoclonus: clinical reappraisal and review of literature. Neurology 2014;83:1862-1870.

Vilter RW. Vidarabine-associated encephalopathy and myoclonus. Antimicrob Agents Chemother 1986;29:933-935.

Vural A, and Tezer FI. Myoclonus induced by haloperidol in the intensive care unit. $J$ Neuropsychiatry Clin Neurosci 2012;24:E41.

Wallace DM, Ross BH, and Thomas CK. Motor unit behavior during clonus. J Appl Physiol (1985) 2005;99:2166-2172.

Werhahn KJ, Brown P, Thompson PD, and Marsden CD. The clinical features and prognosis of chronic posthypoxic myoclonus. Mov Disord 1997;12:216-220.

Wijdicks EF, Campeau NG, and Miller GM. MR imaging in comatose survivors of cardiac resuscitation. AJNR Am J Neuroradiol 2001;22:1561-1565.

Wijdicks EF, Hijdra A, Young GB, Bassetti CL, and Wiebe S. Practice parameter: prediction of outcome in comatose survivors after cardiopulmonary resuscitation (an evidence-based review): report of the Quality Standards Subcommittee of the American Academy of Neurology. Neurology 2006;67:203-210.

Wijdicks EF, Parisi JE, and Sharbrough FW. Prognostic value of myoclonus status in comatose survivors of cardiac arrest. Ann Neurol 1994;35:239-243. 
Wijman CA, Mlynash M, Caulfield AF, Hsia AW, Eyngorn I, Bammer R, Fischbein N, Albers GW, and Moseley M. Prognostic value of brain diffusion-weighted imaging after cardiac arrest. Ann Neurol 2009;65:394-402.

Wu O, Sorensen AG, Benner T, Singhal AB, Furie KL, and Greer DM. Comatose patients with cardiac arrest: predicting clinical outcome with diffusion-weighted MR imaging. Radiology 2009;252:173-181.

Wyllie AR, Bayliff CD, and Kovacs MJ. Myoclonus due to chlorambucil in two adults with lymphoma. Ann Pharmacother 1997;31:171-174.

Yamaoka H, Tomemori N, and Hayama K. The Lance-Adams syndrome following cardiopulmonary resuscitation: A report of two cases. J Anesth 1994;8:349-351. Yoneda M. [Diagnosis and treatments of Hashimoto's encephalopathy]. Rinsho Shinkeigaku 2012;52:1240-1242.

Yoshida K, Moriwaka F, Matsuura T, Hamada T, and Tashiro K. Myoclonus and seizures in a patient with parkinsonism: induction by levodopa and its confirmation on SEPs. Jpn J Psychiatry Neurol 1993;47:621-625.

Young RR, and Shahani BT. Asterixis: one type of negative myoclonus. Adv Neurol 1986;43:137-156.

Zamidei L, Bandini M, Michelagnoli G, Campostrini R, and Consales G. Propriospinal myoclonus following intrathecal bupivacaine in hip surgery: a case report. Minerva Anestesiol 2010;76:290-293.

Zandbergen EGJ, Hijdra A, Koelman JHTM, Hart AAM, Vos PE, Verbeek MM, and de Haan RJ. Prediction of poor outcome within the first 3 days of postanoxic coma. Neurology 2006;66:62-68.

Zhang YX, Liu JR, Jiang B, Liu HQ, Ding MP, Song SJ, Zhang BR, Zhang H, Xu B, Chen $\mathrm{HH}$, Wang ZJ, and Huang JZ. Lance-Adams syndrome: a report of two cases. J Zhejiang Univ Sci B 2007;8:715-720. 


\section{Figure Legends}

Figure 1: Schematic illustration of electromyographic correlates of positive and negative myoclonus during sustained muscle contraction.

Figure 2: Electroencephalogram-electromyogram (EEG-EMG) polygraphic records in a patient with progressive myoclonus epilepsy manifesting positive myoclonus in the hands at rest. Note that most myoclonic jerks are associated with a spike-andwave complex on EEG. EEG recorded in reference to ipsilateral earlobe electrode, and negativity shown upward. ECR, extensor carpi radialis muscle; 1st DI, first dorsal interosseous muscle; Rt, right (reproduced from Shibasaki and Hallett, 2005 with kind permission from John Wiley and Sons).

Figure 3: Hypoxic-ischemic encephalopathy with hyperintense thalami and cortical grey matter of a patient with cortical myoclonus (Serial axial diffusion weighted imaging; on 1.5-T MRI).

Figure 4: Posterior reversible encephalopathy syndrome (PRES) with widespread confluent subcortical hyperintensities in the posterior circulation of a patients with myoclonus following hypertensive crisis (Serial axial FLAIR; on 1.5-T MRI).

Figure 5: Current recommendations of pharmacotherapy for myoclonus according to the neuroanatomical origin (based on and adapted from (Dijk and Tijssen, 2010)). 
*Polytherapy with 3-4 drugs is more effective than monotherapy, particularly for cortical myoclonus.

$\mathrm{DBS}=$ deep brain stimulation . 
Table 1: The classification of myoclonic movements (based on the work of $\mathrm{S}$. Fahn et al. (Dijk and Tijssen,2010; Fahn,2002))

\begin{tabular}{l|l|l}
\hline Clinical classification & Etiological classification & $\begin{array}{l}\text { Neuroanatomical } \\
\text { classification }\end{array}$ \\
\hline \hline Involved muscle groups & Physiological myoclonus & Cortical myoclonus \\
Temporal distribution & - Syncope related myoclonus & Subcortical myoclonus \\
Synchronization & - Startle & Spinal myoclonus \\
Relation to motor activity & - Hickups & Peripheral myoclonus \\
Sensitivity to stimuli & Sleep onset myoclonus & \\
Positive or negative (“asterixis”) & Hereditary myoclonus \\
& - Hereditary myoclonic-dystonia & \\
& - Hereditary hyperekplexia & \\
& Epileptic myoclonus \\
& Symptomatic myoclonus & \\
& (details in Table 2) \\
& Psychogenic myoclonus & \\
\hline
\end{tabular}


Table 2: Causes of symptomatic myoclonus and its neuroanatomical origin in adult ICU-patients

\begin{tabular}{|c|c|c|}
\hline $\begin{array}{l}\text { Neuroanatomical } \\
\text { origin of myoclonus }\end{array}$ & $\begin{array}{l}\text { Critical illness or } \\
\text { exposures }\end{array}$ & Representative reference \\
\hline \multirow[t]{14}{*}{$\begin{array}{l}\text { Cerebral cortex } \\
\text { (and sometimes subcortical) }\end{array}$} & $\begin{array}{l}\text { Intoxication/drug related } \\
\text { encephalopathy }\end{array}$ & \\
\hline & Anesthetic drugs & $\begin{array}{l}\text { Etomidate (Laughlin and Newberg, } 1985 \text {; Lumley and Morgan, } 198 \\
\text { Propofol (Tam et al.,2009) } \\
\text { Enflurane (Ng,1980) }\end{array}$ \\
\hline & Opioids & $\begin{array}{l}\text { Hydromorphone (Babul and Darke,1992; Patel et al.,2006) } \\
\text { Morphine (Potter et al.,1989) } \\
\text { Fentanyl (Stuerenburg et al.,2000) }\end{array}$ \\
\hline & $\begin{array}{l}\text { Non-steroidal anti- } \\
\text { inflammatory drugs }\end{array}$ & Diclofenac (Bandelot and Mihout, 1978) \\
\hline & Neuroleptic drugs & $\begin{array}{l}\text { Haloperidol (Vural and Tezer,2012) } \\
\text { Serotonin (Pedavally et al.,2014) } \\
\text { Quetiapine (Strachan and Benoff,2006) }\end{array}$ \\
\hline & Antiepileptic drugs & $\begin{array}{l}\text { Carbamazepine (Magaudda and Di Rosa,2012) } \\
\text { Oxcarbazepine (Fanella et al.,2013) } \\
\text { Lamotrigin (Algahtani et al.,2014) } \\
\text { Topiramate (Miller et al.,2010) } \\
\text { Pregabalin and gabapentin (Ege et al.,2008; Healy et al.,2009; } \\
\text { Hellwig and Amtage,2008) } \\
\text { Phenytoin (Duarte et al.,1996) } \\
\text { Valproic acid (Gardner et al.,2009) }\end{array}$ \\
\hline & Antidepressants & $\begin{array}{l}\text { Lithium (Caviness and Evidente,2003) } \\
\text { Tricyclic antidepressants (Evidente and Caviness, 1999), } \\
\text { Clozapine (Praharaj et al.,2010) }\end{array}$ \\
\hline & Dopamine agonists & $\begin{array}{l}\text { Levodopa (Yoshida et al.,1993) } \\
\text { Bromocriptine (Buchman et al.,1987) }\end{array}$ \\
\hline & Cardiac medication & $\begin{array}{l}\text { Diltiazem (Jeret,2002) } \\
\text { Propafenone (Chua et al.,1994) }\end{array}$ \\
\hline & Antibiotic drugs & $\begin{array}{l}\text { Imipenem (Frucht and Eidelberg,1997) } \\
\text { Cefepime (Fugate et al.,2013) } \\
\text { Penicillin (Sackellares and Smith,1979) } \\
\text { Gentamycin (Sarva and Panichpisal,2012) } \\
\text { Ciprofloxacin (Jayathissa et al.,2010) } \\
\text { Piperazine (Kompf and Neundorfer,1974) }\end{array}$ \\
\hline & Antihistamines & Antihistamines (Irioka et al.,2008) \\
\hline & Cytostatic drugs & Vidarabine (Vilter, 1986) \\
\hline & Chemotherapeutics & $\begin{array}{l}\text { Busulfan (Denison and Alghzaly,2006) } \\
\text { Chlorambucil (Wyllie et al.,1997) } \\
\text { Ifosfamide (Savica et al.,2011) }\end{array}$ \\
\hline & Heavy metals & $\begin{array}{l}\text { Aluminium (Russo et al.,1992) } \\
\text { Bismuth (Teepker et al.,2002) } \\
\text { Lead (Hansen and Sharp,1978) } \\
\text { Magnanese (Ono et al.,2002) }\end{array}$ \\
\hline \multirow[t]{5}{*}{$\begin{array}{l}\text { (Spinal cord with } \\
\text { tetrahydrocannabinol) }\end{array}$} & IIlicit drugs (or withdrawal) & $\begin{array}{l}\text { Cocaine (Scharf, 1989) } \\
\text { Tetrahydrocannabinol (Lozsadi et al.,2004) } \\
\text { Alcohol withdrawal (Drake,1983) }\end{array}$ \\
\hline & $\begin{array}{l}\text { Vascular-hypoxic } \\
\text { encephalopathy }\end{array}$ & $\begin{array}{l}\text { Myoclonus with severe hypoxic-ischemic encephalopathy } \\
\text { (Werhahn et al.,1997; Wijdicks et al.,1994) } \\
\text { Lance-Adams syndrome (Lance and Adams, 1963; Yamaoka et } \\
\text { al.,1994) }\end{array}$ \\
\hline & Epilepsy & $\begin{array}{l}\text { Epilepsia partialis continua (Lim et al.,2004) } \\
\text { Nonconvulsive seizures and status epilepticus (Fernandez-Tor } \\
\text { and Diaz-Castroverde,2004) } \\
\text { Progressive myoclonus epilepsy (Berkovic et al.,1991) }\end{array}$ \\
\hline & HIV encephalopathy & (Canafoglia et al.,2003; Kanjanasut et al.,2010) \\
\hline & Metabolic encephalopathies & $\begin{array}{l}\text { Uremic (Artieda et al.,1992; Stark,1981; Tedeschi et al.,1982) } \\
\text { Hepatic encephalopathy (Butz et al.,2014) } \\
\text { Rarely hyper- and hypoglycemic encephalopathy }\end{array}$ \\
\hline
\end{tabular}




\begin{tabular}{|c|c|c|}
\hline & Prion diseases & Creutzfeldt-Jakob disease (Binelli et al.,2010; Chen et al.,2010) \\
\hline $\begin{array}{l}\text { (subcortical in SSPE, mumps } \\
\text { and paraneoplastic } \\
\text { encephalitis) }\end{array}$ & Encephalitides & $\begin{array}{l}\text { Viral (HSV (Park et al.,2011) } \\
\text { EBV (Lee et al.,2014) } \\
\text { West Nile virus (Birlutiu and Birlutiu,2014; Cooper and Said,2014 } \\
\text { SSPE (Sharma and Biswas,2013; Shibasaki and Hallett,2005) } \\
\text { Mumps infections (Kang and Kim,2014) } \\
\text { Autoimmune (Balint et al.,2013; DeFelipe-Mimbrera et al.,2014; } \\
\text { Ghoreishi et al.,2013; Leigh et al.,1980; Smith et al.,2011; Stern et } \\
\text { al.,2014; Uehara et al.,2011) } \\
\text { Paraneoplastic (Berger and Mehari,1999; Kim et al.,2009; Kumar } \\
\text { et al.,2005; Morales La Madrid et al.,2012; Mukherjee et al.,2004; } \\
\text { Rickman et al.,2000; Thumen and Moser,2010) }\end{array}$ \\
\hline \multirow[t]{4}{*}{ Subcortical } & Traumatic brain injury & (Birbamer et al.,1993; Jacob and Chand,1999) \\
\hline & Heatstroke & (Bazille et al.,2005) \\
\hline & $\begin{array}{l}\text { Posterior reversible } \\
\text { encephalopathy syndrome }\end{array}$ & (Boland et al.,2012) \\
\hline & Intrathecal anesthesia & (Zamidei et al.,2010) \\
\hline \multirow[t]{4}{*}{ Spinal cord } & Traumatic spinal cord injury & (Calancie,2006) \\
\hline & Spinal cord tumors & (Massimi et al.,2009) \\
\hline & Stiff person syndrome & (Meinck et al.,1995) \\
\hline & $\begin{array}{l}\text { Progressive encephalomyelitis } \\
\text { with rigidity and myoclonus } \\
\text { (=stiff person syndrome plus) }\end{array}$ & $\begin{array}{l}\text { (Kraemer and Berlit,2008; Kyskan et al.,2013; Shugaiv et al.,2013; } \\
\text { Spitz et al.,2004) }\end{array}$ \\
\hline Peripheral nervous system & Peripheral nerve lesions & (Assal et al.,1998; Hudson et al.,2013) \\
\hline Peripheral nervous system & Peripheral nerve blocks & (Hudson et al.,2013) \\
\hline
\end{tabular}

HSV = herpes simplex virus; EBV = Ebstein-Barr virus; SSPE = Subacute sclerosing

panencephalitis; HIV = human immunodeficiency virus 
Table 3: The clinical differences between cortical, subcortical, spinal, and peripheral myoclonus

\begin{tabular}{|c|c|c|c|c|}
\hline $\begin{array}{l}\text { Neuroanatomical } \\
\text { generator }\end{array}$ & $\begin{array}{l}\text { Appearance } \\
\text { with }\end{array}$ & Movement & Rhythmicity & $\begin{array}{l}\text { Stimulus } \\
\text { sensitivity }\end{array}$ \\
\hline Cerebral cortex & $\begin{array}{l}\text { Spontaneously } \\
\text { or with } \\
\text { movement } \\
\text { (action } \\
\text { myoclonus) }\end{array}$ & Shock-like & $\begin{array}{l}\text { Irregular, but can be } \\
\text { rhythmic }\end{array}$ & Highly sensitive \\
\hline $\begin{array}{l}\text { Cerebral subcortical } \\
\text { structures }\end{array}$ & $\begin{array}{l}\text { Spontaneously } \\
\text { (brainstem) }\end{array}$ & Less shock-like & Periodic & $\begin{array}{l}\text { Brainstem reflex } \\
\text { myoclonus can be } \\
\text { sensitive }\end{array}$ \\
\hline Spinal cord & Spontaneously & Variable & Periodic or rhythmic & Can be sensitive \\
\hline $\begin{array}{l}\text { Peripheral nervous } \\
\text { system }\end{array}$ & Spontaneously & Shock-like & Arrhythmic & Not sensitive \\
\hline
\end{tabular}


Table 4: The prognostic value of myoclonus in adult ICU-patients with hypoxicischemic brain injury

\begin{tabular}{|c|c|c|c|c|}
\hline Study design & $\begin{array}{l}\text { Time of } \\
\text { examination } \\
\text { of myoclonus }\end{array}$ & $\begin{array}{l}\text { Definition of poor } \\
\text { outcome }\end{array}$ & $\begin{array}{l}\text { Predictive value } \\
\text { of myoclonus } \\
\text { regarding poor } \\
\text { outcome }\end{array}$ & Reference \\
\hline \multicolumn{5}{|l|}{ Prospective studies } \\
\hline Study with 107 patients & After CPR & $\begin{array}{l}\text { Death during hospital } \\
\text { stay }\end{array}$ & $\begin{array}{l}\text { - False-positive } \\
\text { rate } 0 \% \\
\text { - Sensitivity } 43 \% \\
\text { - Specificity } 100 \%\end{array}$ & (Wijdicks et al.,1994) \\
\hline Study with 407 patients & $\begin{array}{l}\text { In first } 3 \text { days } \\
\text { after CPR }\end{array}$ & $\begin{array}{l}\text { Death or vegetative } \\
\text { state at } 1 \text { month }\end{array}$ & $\begin{array}{l}\text { - False-positive } \\
\text { rate } 0 \% \\
\text { - Sensitivity not } \\
\text { provided } \\
\text { - Specificity not } \\
\text { provided }\end{array}$ & $\begin{array}{l}\text { (Zandbergen et } \\
\text { al.,2006) }\end{array}$ \\
\hline Study with 111 patients & $\begin{array}{l}\text { In the first } 3 \\
\text { days after } \\
\text { CPR and } \\
\text { hypothermia }\end{array}$ & $\begin{array}{l}\text { Death during hospital } \\
\text { stay }\end{array}$ & $\begin{array}{l}-7 \% \text { with false- } \\
\text { positive mortality } \\
\text { predictions during } \\
\text { hypothermia } \\
\text { - Sensitivity } 94 \% \\
\text { - Specificity } 96 \%\end{array}$ & (Rossetti et al.,2010) \\
\hline Study with 103 patients & $\begin{array}{l}\text { At day } 3 \text { after } \\
\text { CPR and } \\
\text { hypothermia }\end{array}$ & $\begin{array}{l}\text { Death during hospital } \\
\text { stay }\end{array}$ & $\begin{array}{l}\text { - False-positive } \\
\text { rate } 0 \% \\
\text { - Sensitivity } 8 \% \\
\text { - Specificity } 100 \%\end{array}$ & (Fugate et al.,2010) \\
\hline Study with 61 patients & $\begin{array}{l}\text { After CPR and } \\
\text { hypothermia }\end{array}$ & CPC $3-5$ at 3 months & $\begin{array}{l}\text { - False-positive } \\
\text { rate } 7 \% \\
\text { - Sensitivity } 21 \% \\
\text { - Specificity } 93 \%\end{array}$ & (Rossetti et al.,2012) \\
\hline Study with 471 patients & $\begin{array}{l}\text { After CPR and } \\
\text { hypothermia }\end{array}$ & CPC $3-5$ at discharge & $\begin{array}{l}\text { - False-positive } \\
\text { rate } 9 \% \\
\text { - Sensitivity not } \\
\text { provided } \\
\text { - Specificity not } \\
\text { provided }\end{array}$ & (Seder et al.,2015) \\
\hline \multicolumn{5}{|l|}{ Systematic review } \\
\hline Review including 12 studies & $\begin{array}{l}\text { In the first } 3 \\
\text { days after } \\
\text { CPR } \\
\text { hypothermia }\end{array}$ & $\begin{array}{l}\text { Death or coma after } 1 \\
\text { month or death, coma, } \\
\text { or severe disability } \\
\text { requiring nursing care } \\
\text { after } 6 \text { months }\end{array}$ & $\begin{array}{l}\text { - False-positive } \\
\text { rate } 0 \% \\
\text { - Sensitivity not } \\
\text { provided } \\
\text { - Specificity not } \\
\text { provided }\end{array}$ & (Wijdicks et al.,2006) \\
\hline \multicolumn{5}{|l|}{ Retrospective study } \\
\hline Study with 37 patients & $\begin{array}{l}\text { At day } 3 \text { after } \\
\text { CPR and } \\
\text { hypothermia }\end{array}$ & $\begin{array}{l}\text { No recovery of } \\
\text { awareness during } \\
\text { hospital stay }\end{array}$ & $\begin{array}{l}\text { - False-positive } \\
\text { rate } 0 \% \\
\text { - Sensitivity not } \\
\text { provided } \\
\text { - Specificity not } \\
\text { provided }\end{array}$ & $\begin{array}{l}\text { (Al Thenayan et } \\
\text { al.,2008) }\end{array}$ \\
\hline
\end{tabular}

$\mathrm{CPR}=$ cardiopulmonary resuscitation; $\mathrm{CPC}=$ cerebral performance category 
Table 5: Neuroimaging findings in adult ICU-patients with hypoxic-ischemic encephalopathy

\begin{tabular}{|c|c|c|c|c|c|}
\hline $\begin{array}{l}\text { Imaging } \\
\text { technique \& } \\
\text { study } \\
\text { design } \\
\end{array}$ & $\begin{array}{l}\text { Time of } \\
\text { imaging after } \\
\text { CPR }\end{array}$ & $\begin{array}{l}\text { Neuroimaging } \\
\text { patterns }\end{array}$ & $\begin{array}{l}\text { Definition of poor } \\
\text { outcome }\end{array}$ & $\begin{array}{l}\text { Predictive value for } \\
\text { poor outcome }\end{array}$ & References \\
\hline \multicolumn{6}{|l|}{ Brain CT } \\
\hline $\begin{array}{l}\text { Prospective } \\
\text { study }\end{array}$ & $\begin{array}{l}\text { At a median } 1 \\
\text { days after } \\
\text { CPR and } \\
\text { hypothermia }\end{array}$ & Global cerebral edema & Death in hospital & $\begin{array}{l}\text { - False-positive rate } 0 \% \\
\text { - Sensitivity } 10 \% \\
\text { - Specificity } 100 \%\end{array}$ & $\begin{array}{l}\text { (Fugate et } \\
\text { al.,2010) }\end{array}$ \\
\hline \multicolumn{6}{|l|}{ Brain MRI } \\
\hline $\begin{array}{l}\text { Prospective } \\
\text { study }\end{array}$ & $\begin{array}{l}\text { In the first } 15 \\
\text { days after CPR }\end{array}$ & $\begin{array}{l}\text { Diffuse signal } \\
\text { abnormalities in the } \\
\text { cortex and subcortical } \\
\text { areas or effacement of } \\
\text { the sulci }\end{array}$ & Death in hospital & $\begin{array}{l}\text { - All } 8 \text { patients with } \\
\text { these imaging patterns } \\
\text { died; } 1 \text { of } 2 \text { patients who } \\
\text { survived had subcortical } \\
\text { ischemia } \\
\text { - Sensitivity not provided } \\
\text { - Specificity not provided }\end{array}$ & $\begin{array}{l}\text { (Wijdicks et } \\
\text { al.,2001) }\end{array}$ \\
\hline $\begin{array}{l}\text { Retrospective } \\
\text { study }\end{array}$ & $\begin{array}{l}\text { In first } 7 \text { days } \\
\text { after CPR and } \\
\text { hypothermia }\end{array}$ & $\begin{array}{l}\text { Lower whole brain and } \\
\text { regional median ADC }\end{array}$ & mRS $3-6$ at 6 months & $\begin{array}{l}\text { - Patients with } \mathrm{mRS}>3 \\
\text { had lower median whole } \\
\text { brain and regional ADC } \\
\text { - Sensitivity } 41 \% \\
\text { - Specificity } 100 \%\end{array}$ & $\begin{array}{l}\text { (Wu et } \\
\text { al.,2009) }\end{array}$ \\
\hline $\begin{array}{l}\text { Prospective } \\
\text { study }\end{array}$ & $\begin{array}{l}\text { At a median } 4.1 \\
\text { (good outcome) } \\
\text { and } 9.8 \text { days } \\
\text { (poor outcome) } \\
\text { after CPR }\end{array}$ & $\begin{array}{l}\text { Multilobar, or diffuse } \\
\text { lesion pattern with } \\
\text { cortical involvement on } \\
\text { DWI and FLAIR }\end{array}$ & CPC $4-5$ at discharge & $\begin{array}{l}\text { - False-positive rate } 0 \% \\
\text { - Sensitivity } 88 \% \\
\text { - Specificity } 100 \%\end{array}$ & $\begin{array}{l}\text { (Topcuoglu } \\
\text { et al.,2009) }\end{array}$ \\
\hline $\begin{array}{l}\text { Prospective } \\
\text { study }\end{array}$ & $\begin{array}{l}\text { In the first } 7 \\
\text { days after CPR } \\
\text { with } \\
\text { hypothermia }\end{array}$ & $\begin{array}{l}\text { ADC } \\
<650 \times 10^{6} \mathrm{~mm}^{2} / \mathrm{sec}\end{array}$ & Death in hospital & $\begin{array}{l}\text { - False-positive rate } 0 \% \\
\text { - Sensitivity } 81 \% \\
\text { - Specificity } 100 \%\end{array}$ & $\begin{array}{l}\text { (Wijman et } \\
\text { al.,2009) }\end{array}$ \\
\hline $\begin{array}{l}\text { Prospective } \\
\text { study }\end{array}$ & $\begin{array}{l}\text { At } 48 \text { hours } \\
\text { after CPR with } \\
\text { hypothermia }\end{array}$ & $\begin{array}{l}\text { Global ischemia or } \\
\text { focal ischemia with } \\
\text { total lesion volume } \\
>20 \mathrm{~mL} \text { on DWI }\end{array}$ & CPC $3-5$ at 6 months & $\begin{array}{l}\text { - False positive rate } 0 \% \\
\text { - Sensitivity } 77 \% \\
\text { - Specificity } 92 \%\end{array}$ & $\begin{array}{l}\text { (Choi et } \\
\text { al.,2010) }\end{array}$ \\
\hline $\begin{array}{l}\text { Prospective } \\
\text { study }\end{array}$ & $\begin{array}{l}\text { In the first } 5 \\
\text { days after CPR } \\
\text { with } \\
\text { hypothermia }\end{array}$ & $\begin{array}{l}\text { Cortical and/or deep } \\
\text { grey nuclei lesions }\end{array}$ & Death at 6 months & $\begin{array}{l}\text { - False positive rate } 0 \% \\
\text { - Sensitivity } 100 \% \\
\text { - Specificity } 100 \%\end{array}$ & $\begin{array}{l}\text { (Cronberg et } \\
\text { al.,2011) }\end{array}$ \\
\hline $\begin{array}{l}\text { Retrospective } \\
\text { study }\end{array}$ & $\begin{array}{l}\text { Between } 1 \text { and } \\
150 \text { days after } \\
\text { CPR }\end{array}$ & $\begin{array}{l}\text { Changes in large } \\
\text { areas of the cerebral } \\
\text { cortex and the deep } \\
\text { grey matter on T2 and } \\
\text { DWI }\end{array}$ & $\begin{array}{l}\text { Death, profound cognitive } \\
\text { impairment and persistent } \\
\text { vegetative state, } \\
\text { minimally area states or } \\
\text { severe physical } \\
\text { impairment at discharge }\end{array}$ & $\begin{array}{l}\text { - False positive rate } 0 \% \\
\text { - Sensitivity } 41 \% \\
\text { - Specificity } 60 \%\end{array}$ & $\begin{array}{l}\text { (Howard et } \\
\text { al.,2012) }\end{array}$ \\
\hline $\begin{array}{l}\text { Prospective } \\
\text { study }\end{array}$ & $\begin{array}{l}\text { At a median of } \\
166 \text { minutes } \\
\text { after CPR }\end{array}$ & $\begin{array}{l}\text { Predefined brain } \\
\text { regions were } \\
\text { qualitatively scored on } \\
\text { DWI according to } \\
\text { severity of abnormality } \\
\text { on a scale from } 0-4\end{array}$ & CPC $3-5$ at discharge & $\begin{array}{l}\text { - False positive rate } 0 \% \\
\text { - Sensitivity } 92-100 \% \\
\text { - Specificity } 100 \%\end{array}$ & $\begin{array}{l}\text { (Park et } \\
\text { al.,2015) }\end{array}$ \\
\hline
\end{tabular}


$\mathrm{CT}=$ computed tomography; $\mathrm{MRI}=$ magnetic resonance imaging; $\mathrm{CPR}=$ cardiopulmonary resuscitation; $A D C=$ apparent diffusion coefficient; $D W I=$ diffusionweighted imaging; FLAIR = fluid attenuated inversion recovery Outcome rating scales: $\mathrm{CPC}=$ Cerebral Performance Categories Scale; $\mathrm{GOS}=$ Glasgow Outcome Scale; mRS = modified Ranking Scale 
Sutter et al. $\quad 48$

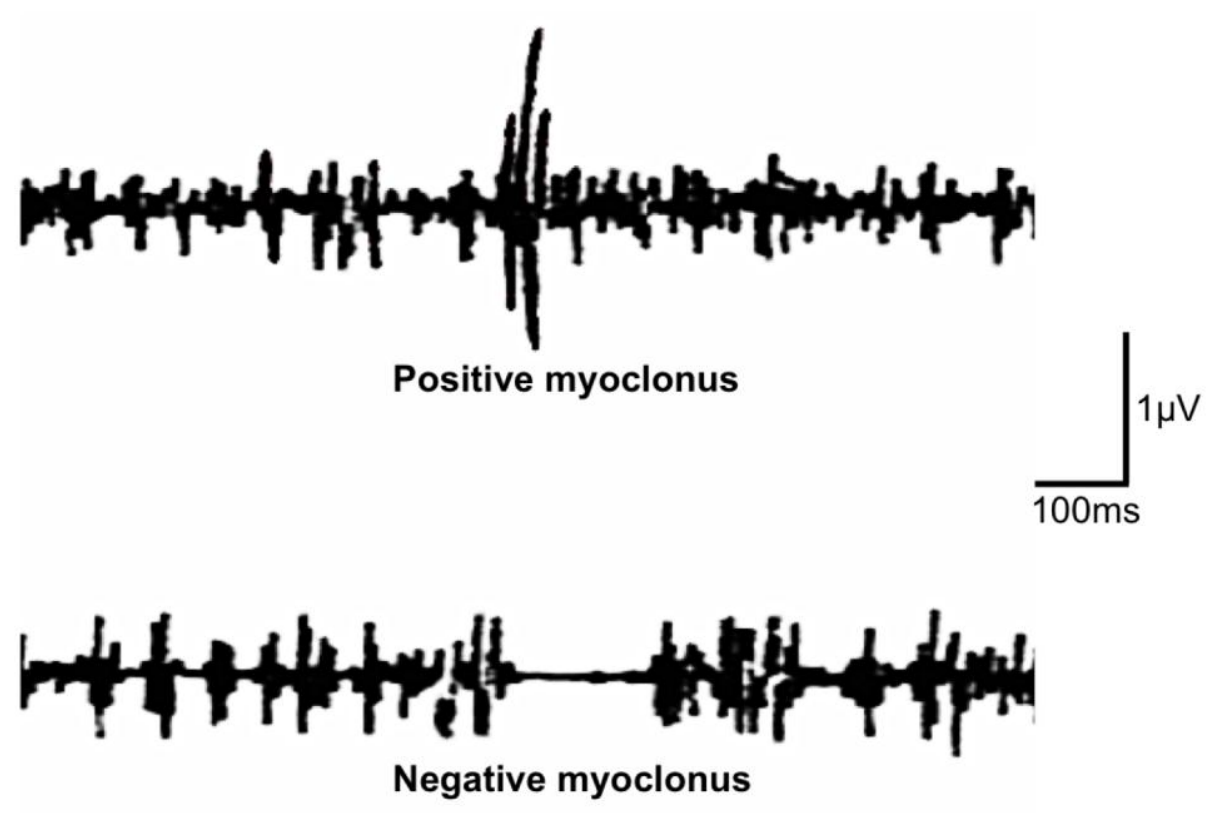




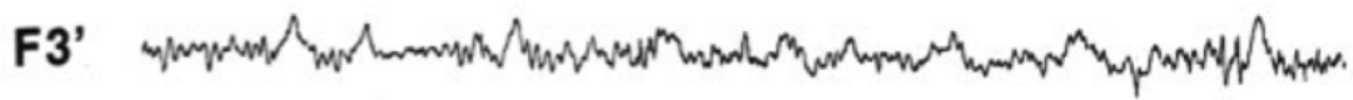

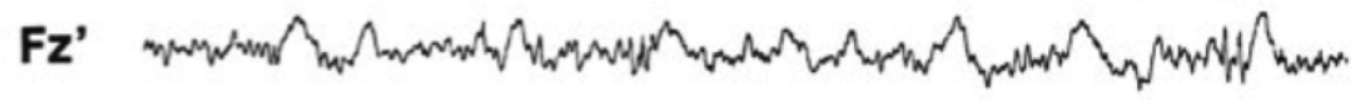

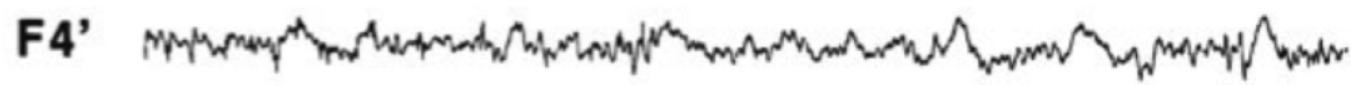

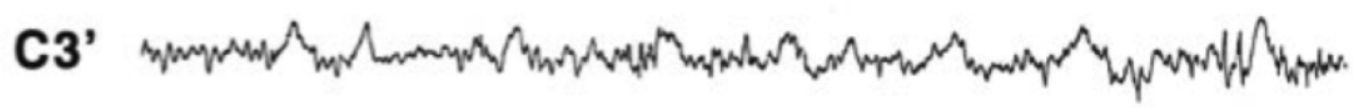

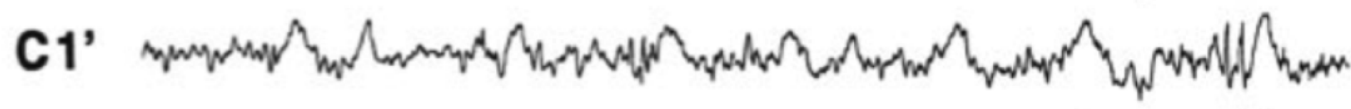

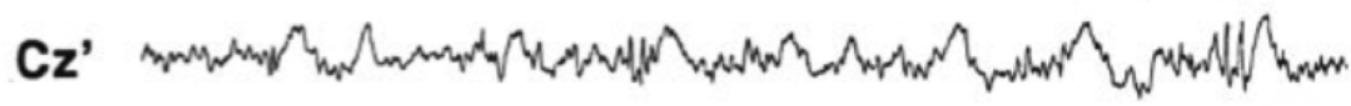

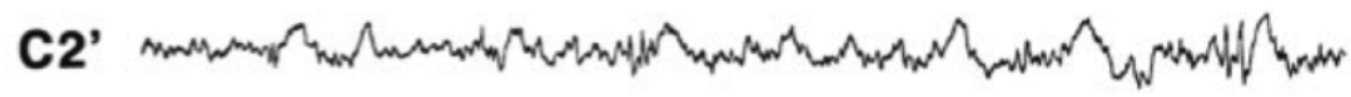

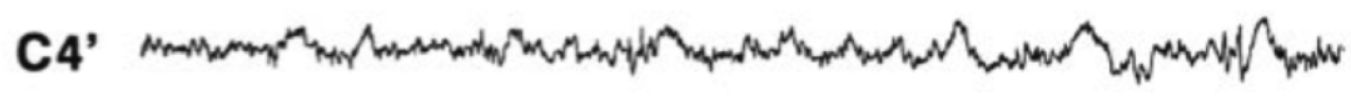

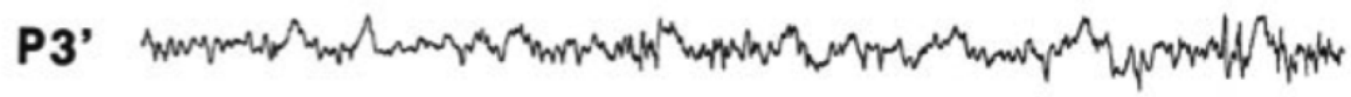

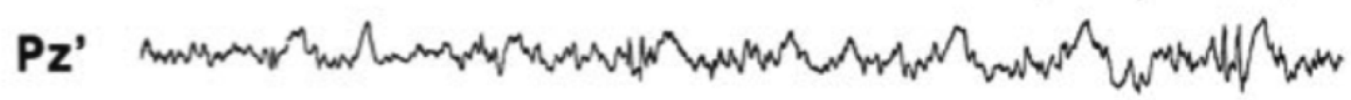

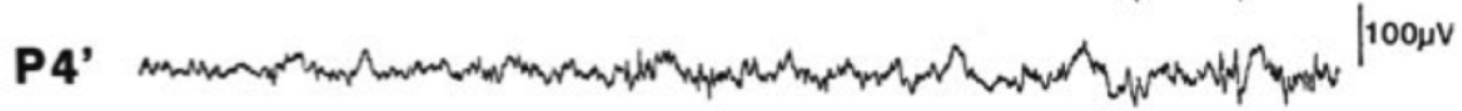

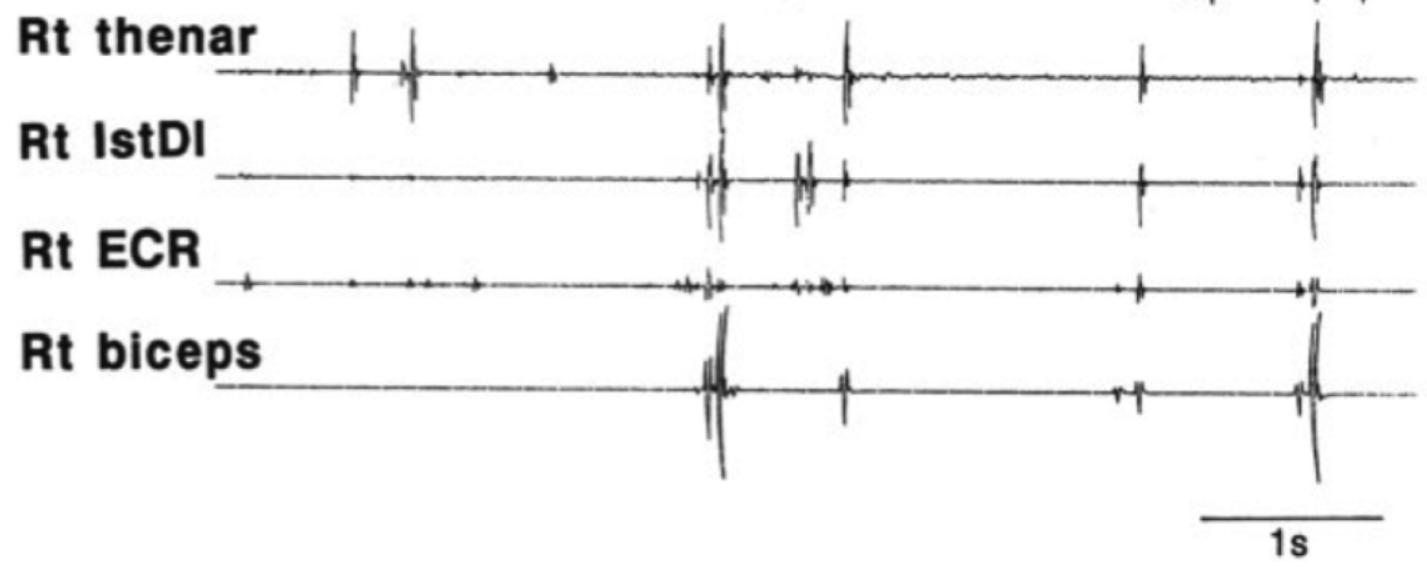


Sutter et al. 50

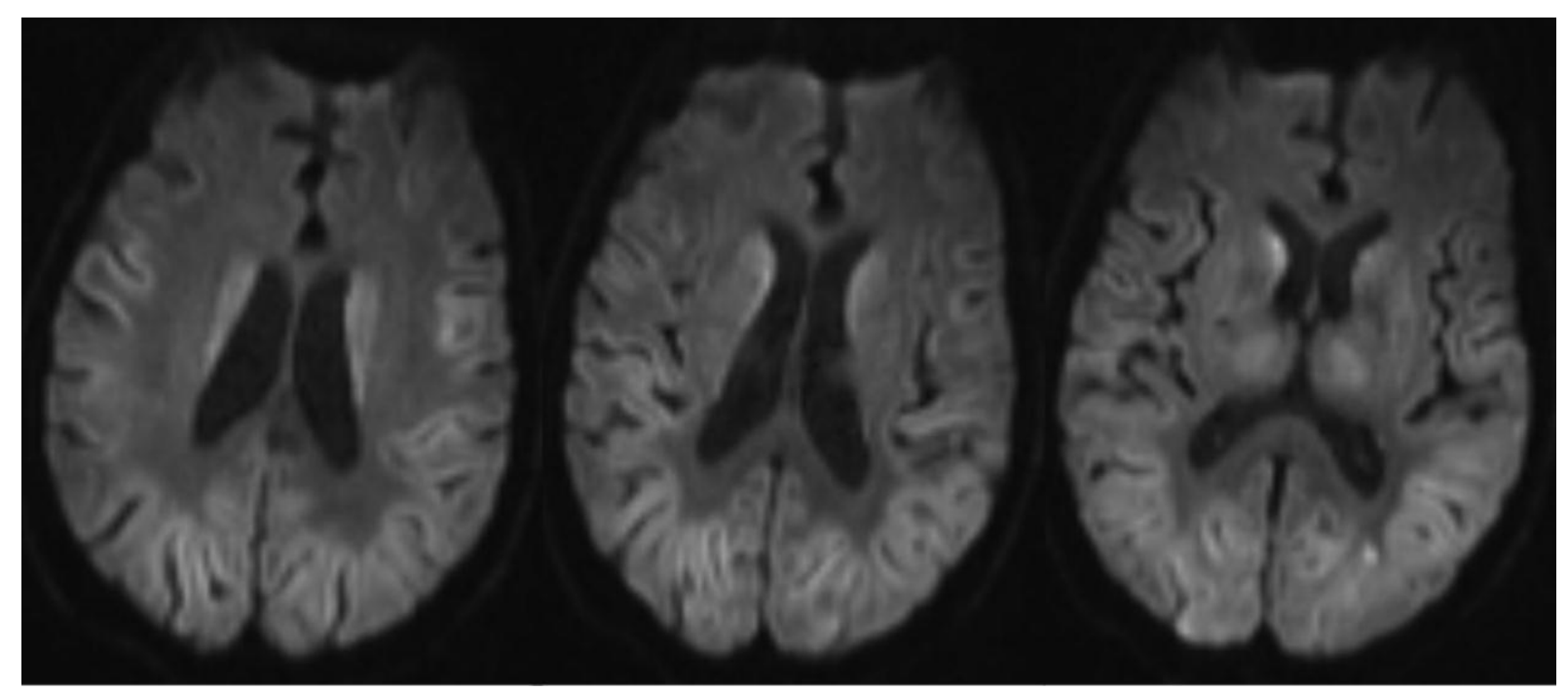


Sutter et al. $\quad 51$

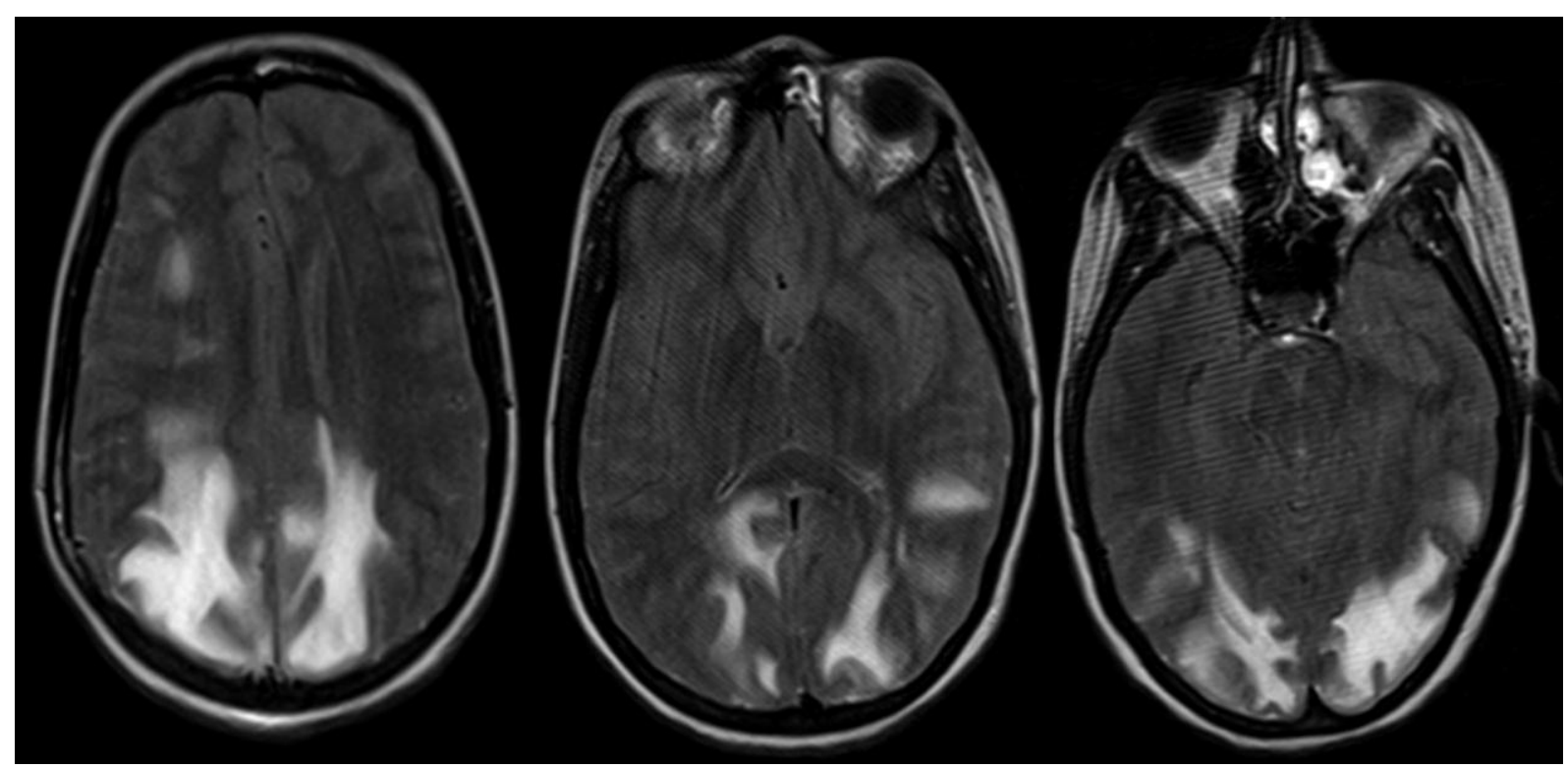




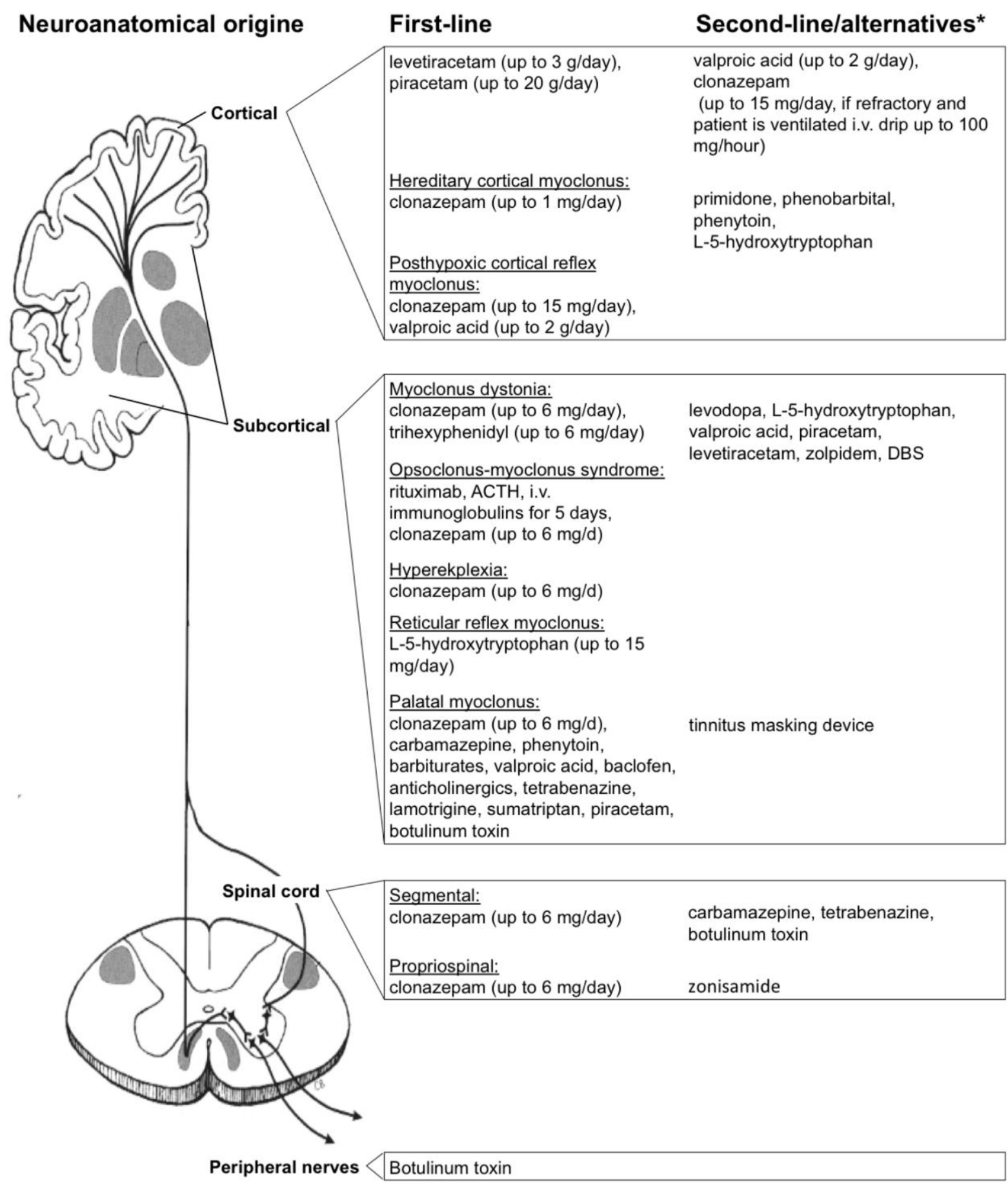

